\title{
Within-field variations in sugar beet yield and quality and their correlation with environmental variables in the East of England
}

Article

Accepted Version

Creative Commons: Attribution-Noncommercial-No Derivative Works 4.0

Mahmood, S. A. and Murdoch, A. J. (2017) Within-field variations in sugar beet yield and quality and their correlation with environmental variables in the East of England. European Journal of Agronomy, 89. pp. 75-87. ISSN 1161-0301 doi: https://doi.org/10.1016/j.eja.2017.05.007 Available at https://centaur.reading.ac.uk/71368/

It is advisable to refer to the publisher's version if you intend to cite from the work. See Guidance on citing.

To link to this article DOI: http://dx.doi.org/10.1016/j.eja.2017.05.007

Publisher: Elsevier

All outputs in CentAUR are protected by Intellectual Property Rights law, including copyright law. Copyright and IPR is retained by the creators or other copyright holders. Terms and conditions for use of this material are defined in the End User Agreement. 


\section{CentAUR}

Central Archive at the University of Reading

Reading's research outputs online 
Within-field variations in sugar beet yield and quality and their correlation with environmental variables in the East of England.

Authors: Salar A. Mahmood, Alistair J. Murdoch

School of Agriculture, Policy and Development, University of Reading

Earley Gate, P.O. Box 237, Reading, Berks RG6 6AR, UK

Corresponding author: Alistair J. Murdoch, a.j.murdoch@ reading.ac.uk

Published in European Journal of Agronomy 2017 in press 


\section{Highlights}

- First publication of field maps for sugar beet crop value and quality

- Patches of lowest crop value in fields were $7-56 \%$ of maximum

- High yielding patches had higher plant populations, soil moisture and organic matter

- Amino acid and potassium in roots were associated with soil type and topography

- Uniform agronomy of sugar beet fields may lead to sub-optimal use of inputs

\section{Graphical summary}

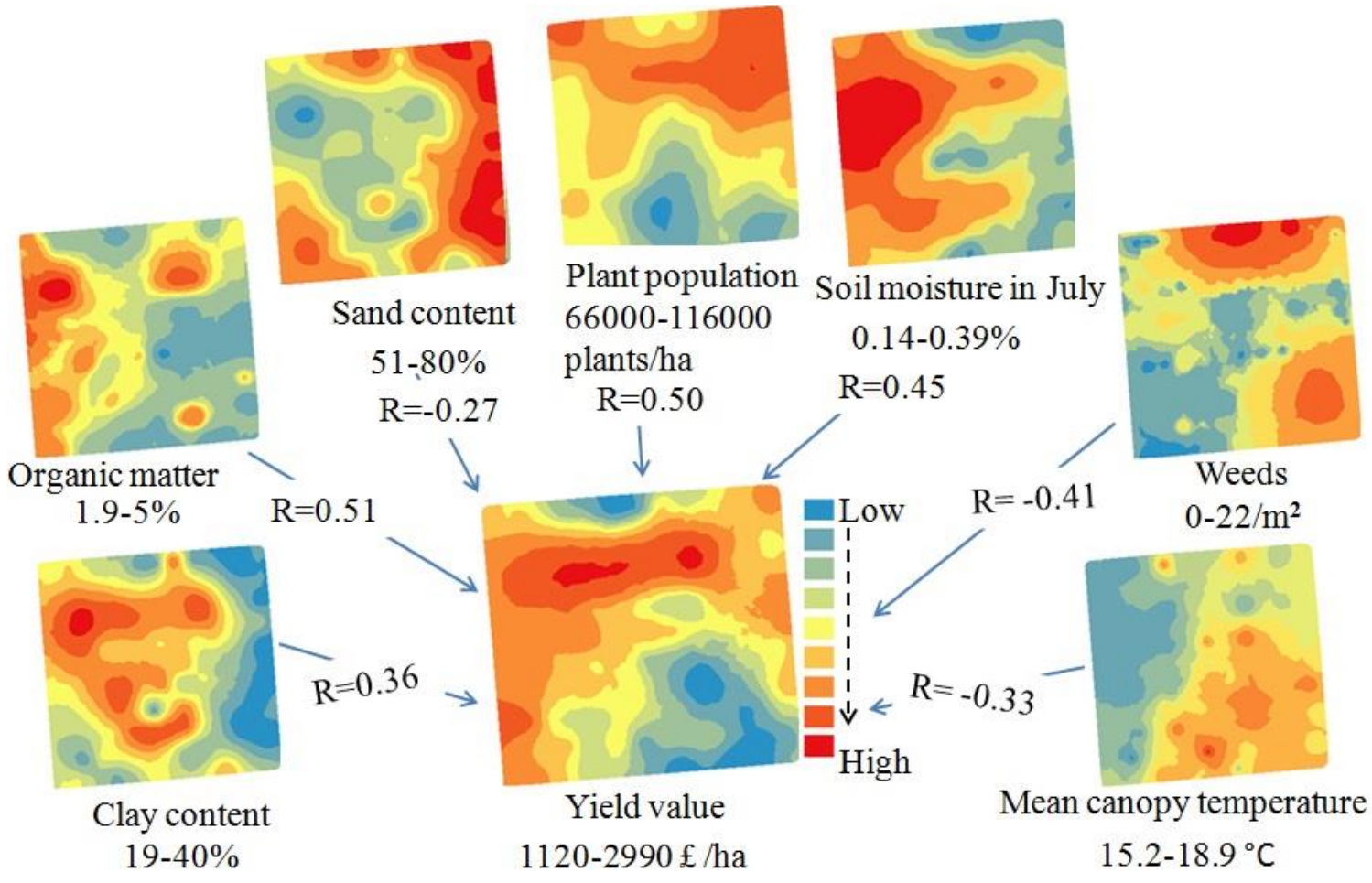

Field maps of variability of potential driving variables of sugar beet yield value in White Patch field at

Brooms Barn Research Station in the east of England in 2012. It is a 9 ha field, measuring approximately 300 x 300 m. Field correlations (R) with yield value are shown for crop and weed population densities, for some soil variables (clay, organic matter, sand and moisture in July) and for mean canopy temperature over the growing season. 


\begin{abstract}
Spatial variability of sugar beet yield and quality within fields and their correlation with environmental variables was investigated in order to explore the potential for more precise agronomy. In three uniformly-managed, commercial sugar beet fields in the east of England spatial variation in the commercial value of the sugar yield ranged from $£ 230$ to $£ 3320$ per hectare. This variation was not random; there were high and low yielding patches in each field. Sugar beet root yield was positively correlated with the spatial distribution of crop plant population, soil organic matter and soil moisture, but negatively with weed density and canopy temperature. Correlations of sugar beet yield with soil type, elevation and soil available phosphate, potassium and magnesium were, however, inconsistent between the three fields and over two seasons. With respect to sugar beet quality, spatial variation in the amino acid and potassium concentrations in the sugar beet roots was associated with soil type and elevation, whereas sugar percentage varied randomly in two of the fields. Interventions and research that could help to optimize yield on a spatially-variable basis are discussed.
\end{abstract}

\title{
Keywords: Sugar beet; Yield map; Plant population; Weed competition; Soil map; Precision agriculture.
}

\section{Introduction.}

Commercial sugar beet fields are generally managed uniformly. Soil, however, varies at different spatial and temporal scales within fields (Webster and Oliver, 2007), and this variability, together with spatial variation in biotic constraints such as weeds, pests and diseases, may cause spatial and temporal variability in crop development and yield (Heege, 2013, Oliver et al., 2013). Sugar beet is expected to respond similarly (Richter et al., 2006).

Although yield maps of combinable crops can be produced cheaply and routinely during harvesting (Heege, 2013), yield monitors do not currently feature on sugar beet harvesters. Yield maps reflect crop responses to stresses or other constraints on yield, but different environmental variables may cause similar patterns of stress (Jones and Schofield, 2008). An accurate field map of variables which 
may be influencing yield variation is required to implement more precise crop agronomy. Such maps usually need to be based on field sampling, which is expensive (Webster and Lark, 2012). Moreover, the samples only quantify soil variables where samples are taken (Scannavino et al., 2011) although Kriging can be used to predict the values at unsampled locations provided adequate numbers of samples are available (Oliver, 2010).

Previous research in sugar beet fields has mapped spatial variability of single factors including soil organic matter (Karaman et al., 2009a), soil available nitrogen and phosphate (Franzen, 2004, Karaman et al., 2009b), soil moisture content (Zhang et al., 2007, 2011) and Heterodera schachtii, the beet cyst nematode (Reynolds, 2010, Hbirkou et al., 2011). Associations of this spatial variability with sugar beet growth, yield and quality were not, however, reported. Since within-field variation is likely to be influenced by combined effects of pedo-climatic and biotic factors, it could be misleading to focus on single factors. This paper therefore investigates field scale correlations of sugar beet yield and quality with variation in a range of factors both separately and in combination.

Variation in plant population, especially where a result of poor crop establishment, is likely to affect the ability to detect post-emergence correlations with pedo-climatic variables. Sugar beet yields follow typical asymptotic yield-density relationships (Holliday, 1960, Jaggard and Qi, 2006). In eleven experiments carried out on a range of soil types in England over three growing seasons, yields were maximised in eight of the experiments with 100000 sugar beet plants per hectare, the economic optimum after allowing for seed costs, being 80000 per hectare (Jaggard et al., 2011). These optima, although not the actual yields, were the same in different soil types and locations.

Other biotic constraints also influence the ability to discern impacts of environmental variables, not least of which is weeds. Sugar beet is highly susceptible to weed competition especially in early stages of growth until canopy closure (Kropff et al., 1992). Reflecting this vulnerability to weeds, when this research commenced in 2012, UK sugar beet crops were receiving an average of 4.1 herbicide treatments and sugar beet was treated with more herbicide ( $3.2 \mathrm{~kg}$ active ingredients per hectare) than any other arable crop in the UK (Garthwaite et al., 2013). In the fields where this research was carried 
out, weeds were managed uniformly and received above average treatments, but nevertheless still contained significant weed infestations in patches.

This paper mainly explores associations of both root yield and economic value with pedo-climatic variables within individual fields after accounting for any impacts of crop and weed plant population densities. The long-term goal is to identify opportunities for more precise sugar beet management in relation to pedo-climatic variables.

\section{Materials and methods.}

Three commercial sugar beet fields were selected in the east of England (Table 1). These fields were White Patch at Broom's Barn Research Station, near Bury St. Edmunds (32 km east of Cambridge), and T32 and WO3, near Cambridge (Table 1). Fields were purposively selected on the basis of their having considerable variation in soil type (based on pre-existing soil maps) and topography (elevation and aspect - based on visiting the fields). The farm managers were wholly responsible for managing the crops and applied all inputs (Table 1) uniformly across the sampled areas of each field. White Patch and T32 were studied in 2012, and WO3 in 2013. To facilitate geostatistical analysis (Webster and Oliver, 2007), there were 90-114 samples per field arranged in an irregular grid with some nested samples over shorter distances (Table 1, Figure 1). Yield maps of the preceding crops in T32 and WO3 and a soil map in White Patch were available and guided sampling, especially for locating the nested samples, which were included to enhance the accuracy of the predicted maps (Pereira et al., 2013).

Sample locations were geo-referenced using a differential Global Positioning System (dGPS), Trimble Nomad 900B Mobile Computer in White Patch and T32, while an RTK GPS, Topcon Model GRS-1 (Topcon Positioning Systems, Inc., 7400 National Drive, Livermore, CA 94550 USA) provided more accurate geo-referencing in WO3. The latitude, longitude and altitude data provided by the GPS were used to estimate the slope and aspect of each sample location using ArcGIS software edition 10 (ESRI, Redlands, CA, USA). Except where noted otherwise, crop and soil sampling took place in $2 \times 2 \mathrm{~m}$ plots 
at each sampling location. These plots comprised four rows of sugar beet with $50 \mathrm{~cm}$ spacing between rows.

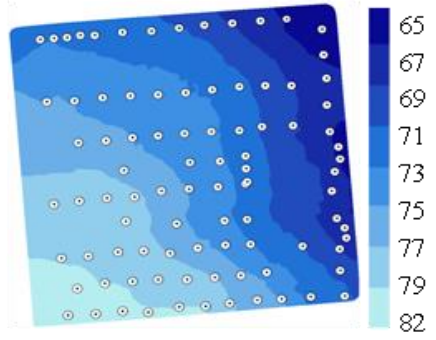

A. White Patch

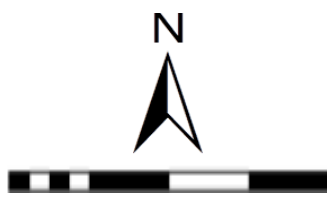

$300 \mathrm{~m}$

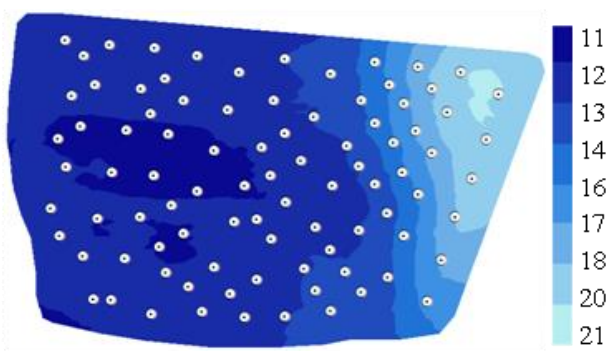

B. T32

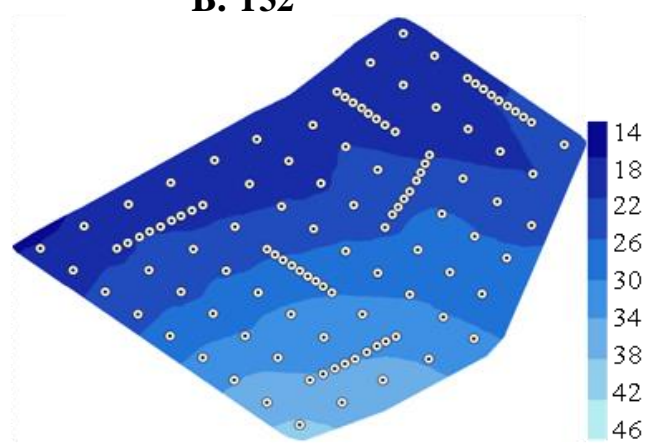

C. WO3

Elevation, m

Figure 1: Kriged elevation maps and the distribution of the sampling points in the fields, White Patch (A), T32 (B) and WO3 (C). Elevations (heights above mean sea level) were obtained from the GPS instruments. Some areas in White Patch were unavailable for sampling.

\subsection{Measurements.}

\subsubsection{Crop assessments}

To improve accuracy, the sugar beet plant population density at each sampling location was assessed by counting plants in $8 \mathrm{~m}^{2}$ ( 4 rows $\mathrm{x} 4 \mathrm{~m}$ ) extending the two-metre plot length used for most measurements by $2 \mathrm{~m}$, taking care to avoid tractor wheelings. Counts were multiplied by 1250 to express the densities on a per hectare basis.

The plots were harvested manually (Table 1) shortly before commercial harvest. The two central rows from each plot $\left(2 \mathrm{~m}^{2}\right)$ were harvested in White Patch and T32 fields. In WO3 the harvested area for some plots had to be increased to include the whole plot $\left(4 \mathrm{~m}^{2}\right)$ or extended to $8 \mathrm{~m}^{2}$ to achieve the 10 $15 \mathrm{~kg}$ samples required for analysis. The roots were dug with a modified (two-pronged) fork to avoid damage and the leaves were separated from the roots by cutting just below the crown using knives 
designed for hand topping sugar beet. The roots were then put in large woven polypropylene sacks (30 $\mathrm{x} 45 \mathrm{~cm}$ ), and sent within $16 \mathrm{~h}$ to the British Sugar factory at Wissington, $45 \mathrm{~km} \mathrm{NE}$ of Cambridge, where they were analysed exactly as for commercial samples.

At the factory the roots were washed and weighed and the clean samples then went through the factory system to determine the sugar content based on polarimetry methods, while the flame photometry was used to measure impurities and the root content of amino acids and potassium in $\mathrm{mg} / 100 \mathrm{gm}$ of beet as specified by the International Commission for Uniform Methods of Sugar Analysis (Whalley and Siegfried, 1964). The yield value was computed as follows:

Yield value $(\mathfrak{f} / \mathrm{ha})=[$ Root yield $(\mathrm{t} / \mathrm{ha})] \times P \times F$

where $P$ was the British Sugar price per tonne of roots (£27.53 and $£ 26.51$ in the 2012 and 2013 seasons, respectively), and $F$ is a quality adjustment to that price, which ranged between 0.72 and 1.32 for sugar percentages in the root between 13 and 20\% (C. Walters, British Sugar, personal communication).

\subsubsection{Weed assessments}

Densities of weeds surviving or emerging after herbicide treatments were counted and identified in the whole plot area $\left(4 \mathrm{~m}^{2}\right)$ (Table 1$)$.

\subsubsection{Soil sampling and analysis.}

Soil was sampled in each plot to a depth of $30 \mathrm{~cm}$ using a $5 \mathrm{~cm}$ diameter Dutch auger in early July (Table 1). Three soil cores were taken diagonally across each $2 \times 2 \mathrm{~m}$ plot, bulked, mixed thoroughly, air dried and then stored in polythene bags at $4{ }^{\circ} \mathrm{C}$ prior to analysis. Percentages of clay and sand were estimated using the hydrometer method (Sheldrick and Wang, 1993). Total soil organic matter was estimated by loss-on-ignition (Jones Jr, 1999). Soil pH and EC and available potassium (K), phosphorus (P) and magnesium (Mg) were measured using Palintest Soil Test Model 10 (Palintest Ltd, Palintest House, Kingsway, Team Valley, UK) using Palintest soil extraction and reagent kits. The tests for $\mathrm{P}$ and $\mathrm{Mg}$ are based on colour comparison methods, while the $\mathrm{K}$ test is based on turbidity (cloudiness). Extraction solutions were $50 \mathrm{~mL}$ of $0.1 \mathrm{M}$ magnesium acetate, $0.5 \mathrm{M}$ sodium bicarbonate 
and 1.0 M potassium chloride for $\mathrm{P}, \mathrm{K}$ and $\mathrm{Mg}$, respectively, to which $2 \mathrm{~mL}$ soil was added ( $\mathrm{P}$ and $\mathrm{K}$ ) or $10 \mathrm{~mL}$ for $\mathrm{Mg}$. Containers were shaken for one minute (P and $\mathrm{K})$ or two minutes $(\mathrm{Mg})$, filtered, and then 10,2 or $1 \mathrm{~mL}$ of filtrate were placed in $10 \mathrm{~mL}$ photometer tubes, for $\mathrm{K}, \mathrm{P}$ and $\mathrm{Mg}$, respectively. Volumes were made up to $10 \mathrm{~mL}$ with deionised water and specific Palintest reagent tablets for each element were added and left for 2, 10 and 5 min, respectively. The photometer was reset to zero by inserting a blank tube after which a sample tube was inserted and the result recorded. Eddy and Johnston (2009) carried out a comparison of these procedures for Palintest Soil Testing Kits with recognised laboratory soil analysis methods. Correlation coefficients for available $\mathrm{K}, \mathrm{P}$ and $\mathrm{Mg}$ were all better than 0.95 .

Soil volumetric moisture content was estimated in the top $20 \mathrm{~cm}$ of the soil profile on different dates (Table 1) using a FieldScout Model TDR 300 (Spectrum Technologies, Aurora, IL 60504, USA). On each date, soil moisture was measured in all plots in a given field within a period of 2-3 $\mathrm{h}$ when it was not raining. 
Table 1: Field operations, sampling and the dates of some measurements in the fields, White Patch, T32 and WO3.

\begin{tabular}{|c|c|c|c|}
\hline & White Patch, 2012 & T32, 2012 & WO3, 2013 \\
\hline Latitude, ${ }^{\circ} \mathbf{N}$ & 52.257 & 52.182 & 52.167 \\
\hline Longitude, ${ }^{\circ} \mathbf{E}$ & 0.573 & 0.105 & 0.143 \\
\hline Area ha & 9 & 12.4 & 14 \\
\hline Previous crop & Winter wheat & Winter wheat & Winter wheat \\
\hline Sugar beet variety & Valeska & Bullfinch & SY Muse \\
\hline Crop drilled & 23 March & 16 March & 5 March \\
\hline Plots harvested & 25 September & 2 October & 26 November \\
\hline Crop plants/ha, (range) & $91000(66000-116000)$ & $95000(70000-115000)$ & $51000(22000-81000)$ \\
\hline Total plots (number) & 91 & 90 & 114 \\
\hline Nested plots (number) & 13 & 15 & 36 \\
\hline Sampling intervals, $\mathbf{m}$ & $24-40$ main grid, 10 nested & 40 main grid, 20 nested & 36 main grid, 9 nested \\
\hline Soil sampling date & 2 July & 7 July & 8 July \\
\hline Canopy data logging & 31 May to 25 September & 1 June to 2 October & 22 May to 26 November \\
\hline No. of data loggers & 45 & 45 & 90 \\
\hline Soil moisture measured & 2 June, 5 July and 13 August & 6 June, 6 July and 13 August & 6 June, 9 July and 11 Sept. \\
\hline Weed assessment & 13 August & 17 August & 20 July \\
\hline Weed species & \multicolumn{2}{|c|}{$\begin{array}{l}\text { Mayweed (Matricaria perforata), Speedwell (Veronica } \\
\text { hederifolia), Fat hen (Chenopodium album), Black-grass } \\
\text { (Alopecurus myosuroides) and Wild-oat (Avena fatua). }\end{array}$} & $\begin{array}{l}\text { Black-grass (Alopecurus } \\
\text { myosuroides) and Brassica } \\
\text { napus. }\end{array}$ \\
\hline Nitrogen, kg $\mathbf{N}$ per ha & 40, 3 April; 80, 13 April & 58, 23 March; 80, 25 May & 60, 9 April (only) \\
\hline \multirow{9}{*}{$\begin{array}{l}\text { Herbicide applications, } \\
\text { amount per ha }\end{array}$} & 17 May: 1.25 L Betanal & 22 March: 3 L Takron. & 14 March: 4 L Takron. \\
\hline & Maxxpro; 1 L Bettix Flo; 1 L & 17 May: 2.5 L Beetup; 0.39 L & 25 April: 1 L Beetup; 0.45 L \\
\hline & Oil. & Oblix 500; $20.5 \mathrm{~g}$ Debut; $0.4 \mathrm{~L}$ & Oblix 500; 0.8 L Target SC; \\
\hline & 24 May: 1.25 L Betanal & Venzar Flo; 0.5 L Defiant; & 1 L Opteman. \\
\hline & Maxxpro; 0.4 L Venzar. & 1.033 L Cropspray 11E. & 7 May: 1.6 L Beetup; 1.55 L \\
\hline & & 22 July: 2.5 L Opteman; 5.16 & Defiant SC; 0.8 L Target SC; \\
\hline & & kg Bittersalz; 0.55 L Laser; & 1.13 L Opteman. \\
\hline & & 1 L Cropspray 11E. & 17 June: 2.46 L Beetup; 0.5 L \\
\hline & & & Defiant; 1 L Cropspray 11E. \\
\hline
\end{tabular}

\subsubsection{Climatological data.}

Weather data for White Patch were recorded at the Broom's Barn weather station located $300 \mathrm{~m}$ from the field. For T32 and WO3, data were obtained from CEDA (2014) for the nearest weather station which was located at Cambridge University Botanic Garden $\left(52.194^{\circ} \mathrm{N}, 0.1294^{\circ} \mathrm{E}, 11 \mathrm{~m}\right.$ above mean 
sea level), $2.1 \mathrm{~km}$ north-east of T32 and $3.2 \mathrm{~km}$ north of WO3. The nearest location capturing global solar radiation was Chilford Hall, Linton $\left(52.1162^{\circ} \mathrm{N}, 0.287^{\circ} \mathrm{E}, 78 \mathrm{~m}\right.$ above mean sea level), Cambridgeshire, $25 \mathrm{~km}$ south-west of White Patch and 11 and $15 \mathrm{~km}$ south-east of WO3 and T32, respectively. The incident solar radiation for each plot was estimated from the figures for global solar radiation combined with the slope and aspect of each plot following the method developed by Kumar et al. (1997).

Crop canopy temperature and humidity were logged with iButton data loggers (Thermocron model DS1922L and Hygrochron model DS1923, Maxim Integrated Inc., Wokingham, UK). Loggers were installed when the plants had two pairs of leaves and temperature was recorded every 30 min until plots were harvested (Table 1). The loggers were shielded from direct solar radiation, wind, rain and wild animals by placing them in the crop canopy in the 2012 season. In 2013, loggers in WO3 were covered by white polystyrene cups, which were kept near the top of the canopy and covered with aluminium foil to reflect radiation. Seasonal mean, minimum and maximum canopy temperatures were calculated. As there were insufficient loggers to place one in every plot (Table 1), they were distributed as evenly as possible to allow mapping. For correlations, temperatures in plots without loggers were estimated by averaging the temperature in the nearest four plots containing loggers.

\subsection{Data analysis.}

Summary statistics were calculated for all variables. An initial indication of variability was provided by the Coefficients of Variation (CV). Skewness values exceeding +1 indicate departure from a normal distribution, and the data were transformed to logarithms to avoid overestimation of the variance (Oliver and Webster, 2014). Variograms were then computed using GenStat $17^{\text {th }}$ edition (Payne, 2009) based on Matheron's Method of Moments (Oliver and Webster 2014) as follows:

$$
\gamma_{h}=\frac{1}{2 m_{h}} \sum_{i=1}^{m_{h}}\left[Z_{x}-Z_{(x+h)}\right]^{2}
$$


Where $\gamma_{h}$ is the semi-variance for $m_{h}$ paired comparisons at lag distance $h$, and $Z_{x}$ and $Z_{(x+h)}$ are the values of the property at two locations separated by distance $h$.

The best fitting variogram model was then selected based on a combination of visual assessment and the lowest residual sum of squares (RSS). For mapping, interpolations were made using ordinary punctual kriging, based on the following equation:

$$
\check{\mathbf{Z}}_{\mathbf{x}_{0}}=\sum_{\mathrm{i}=1}^{\mathbf{n}} \boldsymbol{\lambda}_{\mathbf{i}} \mathbf{Z}_{\mathbf{x}_{\mathbf{i}}}
$$

Where $\breve{Z}_{\mathrm{x} 0}$ is the estimated value of the property at the unsampled location $\left(\mathrm{x}_{0}\right)$ and $\lambda_{\mathrm{i}}$ is the weighting applied to values $\left(\mathrm{Z}_{\mathrm{x}_{\mathrm{i}}}\right)$ at $n$ sampled locations. The sum of weights equalled one to give an unbiased estimate. Interpolations and field maps were then produced for each variable using ArcGIS software edition 10 (ESRI, Redlands, CA, USA: Johnston et al., 2001) based on the variogram's parameters (range, sill and nugget). 

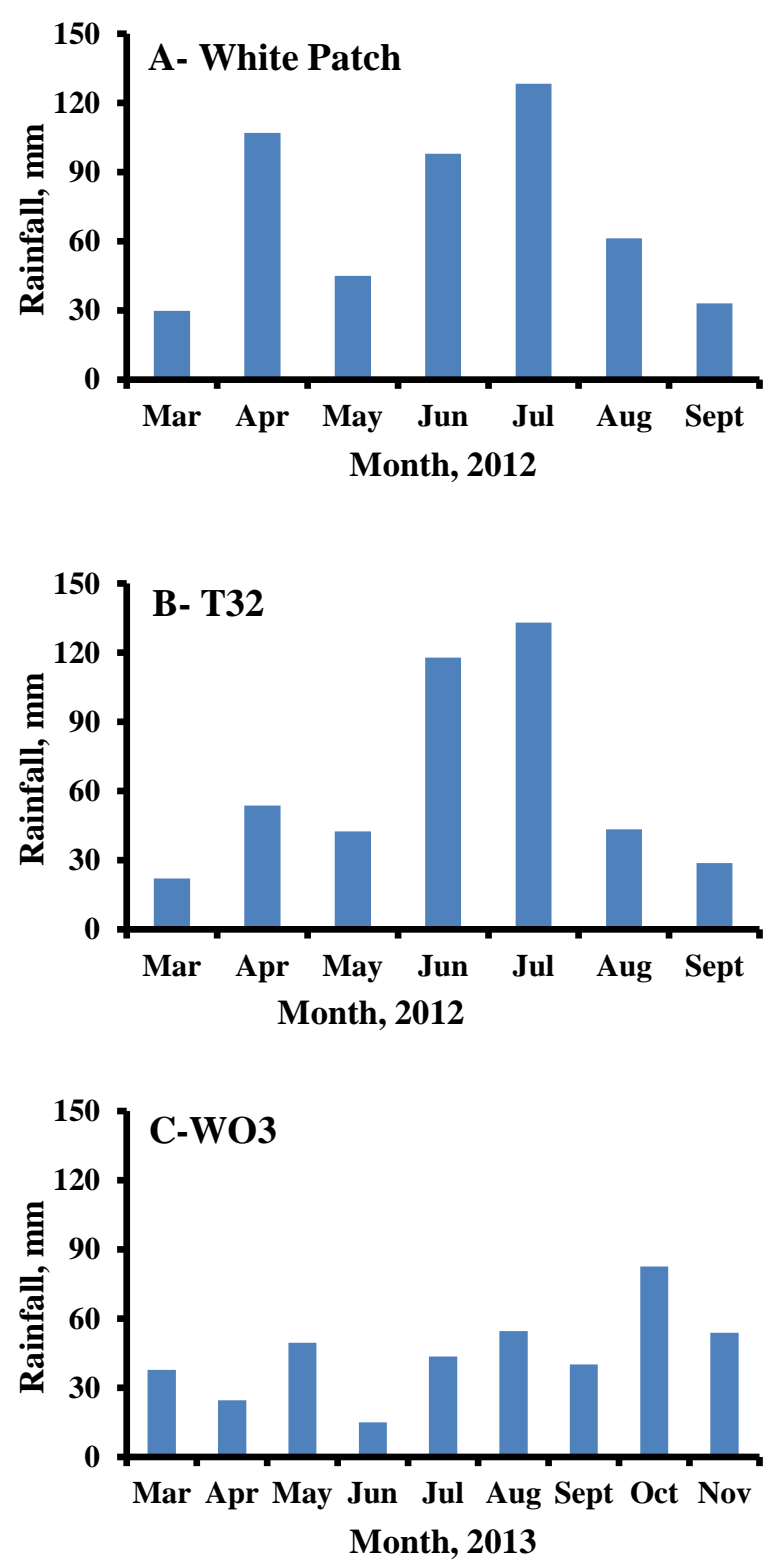
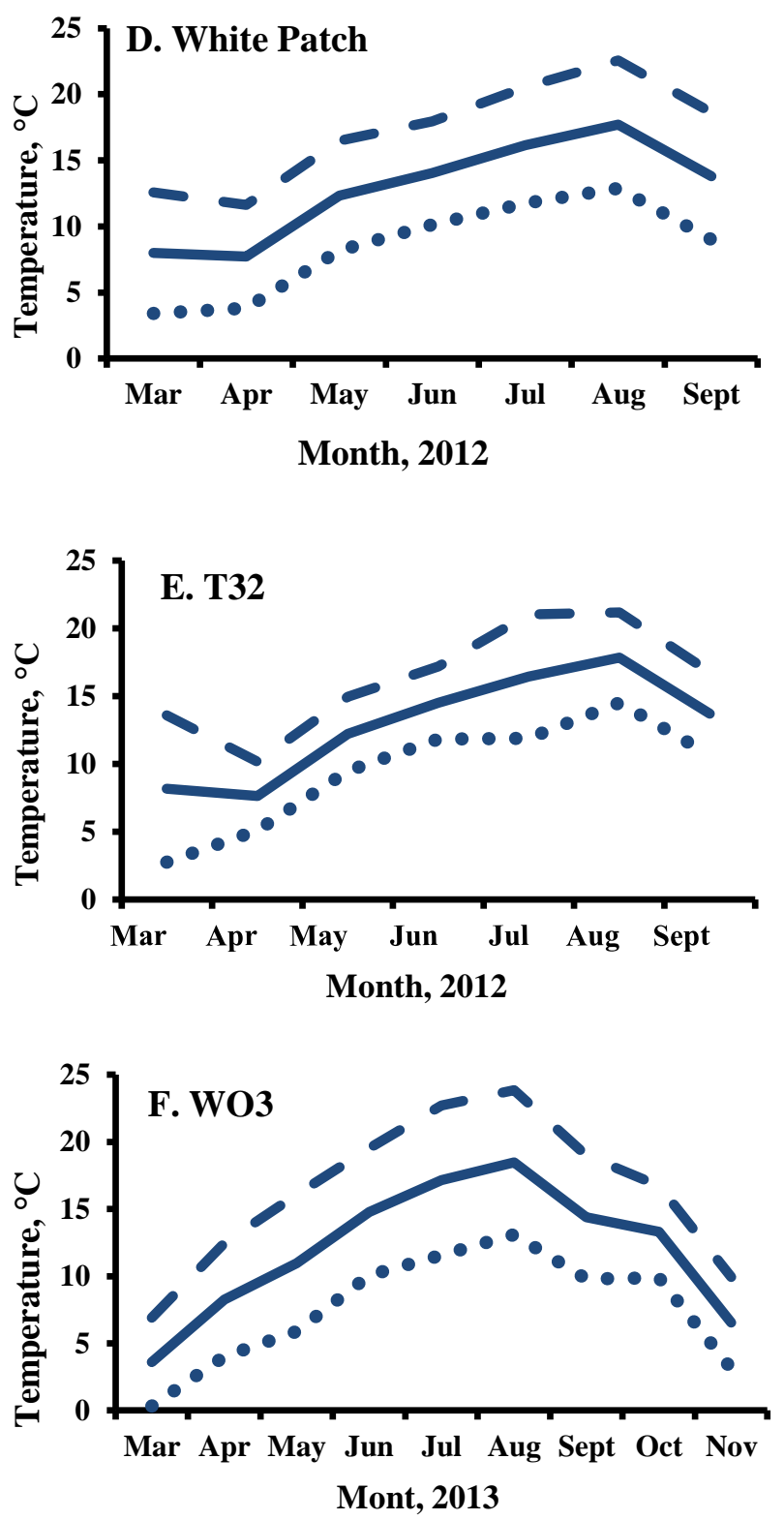

Figure 2: Monthly precipitation (A-C) and mean minimum, mean maximum and overall mean air temperatures (D-F), respectively at weather stations close to White Patch (A, D) and T32 (B, E) in 2012 and WO3 (C, F) in 2013. Data are only shown during the cropping season, which was longer in 2013. 
Overall relationships between individual crop and environmental variables were assessed using Pearson correlation coefficients. Combined or confounded relationships were determined with Redundancy Analyses (RDA) using Canoco version 5 software (Šmilauer and Lepš 2014). RDA is a form of Principal Components, multi-variate regression analysis in which sugar beet yield and quality were identified as response variables and weed and crop plant population densities and environmental factors were used as explanatory variables (Kenkel et al., 2009). The method assumes that the sugar beet yield and quality are a linear multivariate function of the explanatory variables and results are visualised using ordination plots. Since spatial variability of soil moisture content varied similarly at different times, only the measurements from early June were used for the RDA.

\section{Results.}

The relatively high $(\geq 10 \%)$ coefficients of variation $(\mathrm{CV})$ for most variables gives evidence of significant spatial variability in the fields. The highest CVs (76 to 356\%) were for soil available phosphate, magnesium and weeds (Table 2). Conversely, sugar concentration, soil pH, canopy temperature and incident solar radiation were relatively uniform $(\mathrm{CVs}<6 \%$ : Table 2$)$.

Crop plant population densities were optimal in 2012 with mean values of 91065 and 95000 plants/ha in White Patch and T32, respectively (Table 2). By contrast, establishment in WO3 in 2013 was much lower and more variable than the farmer's target of at least 80000 plants/ha, with a mean population density of only 50800 plants/ha, ranging from 22000 to 81000 plants/ha (Tables 1, 2).

The mean root yield and sugar percentage were generally higher in T32, which therefore resulted in a higher mean yield value of $£ 2500$ per ha (Table 2) compared to $£ 1850$ and $£ 1870$ in White Patch and WO3, respectively. The variability in final economic yield was however much higher in WO3 than in T32 with CVs of 32 and $11.3 \%$, respectively (Table 2). Nevertheless, these CVs perhaps mask their financial importance, since yield values ranged from $£ 230$ to $£ 3127, £ 1120$ to $£ 2990$ and $£ 1870$ to 3320 per ha (Table 2) in WO3, White Patch and T32, respectively.

Rainfall during the 2012 growing season (March to September) was abundant amounting to 502 and $441 \mathrm{~mm}$ in White Patch and T32 respectively, whereas it was lower (401 mm) in the longer 2013 
growing season (March to the end of November). Low rainfall shortly after drilling in March and April 2013 was also associated with lower temperatures $\left(<5^{\circ} \mathrm{C}\right)$ than in 2012 (Fig. 2 D-F).

Precipitation in July 2012 was very high (>130 mm; Fig. 2) resulting in uniform and high mean soil moistures of $53(\mathrm{CV}: 8 \%)$ and 41\% (CV: 12.2\%) in White Patch and T32, respectively. By contrast in July 2013, soil moisture in WO3 was only $22 \%$ and more variable (CV: 25\%). Lower precipitation in August in all fields and in WO3 throughout the season led to more variable soil moisture (CVs: 14.6 to $27 \%$ ), probably reflecting variability in soil type and water retention (Table 2).

Incident solar radiation was higher and more variable in WO3 in 2013 compared to White Patch and T32 in 2012. Soil pH was high in all fields due to the chalk soils and was highest (8.4) in White Patch compared to T32 (7.5) and WO3 (7.8) (Table 2). Soil phosphate was almost unavailable in WO3 at the time of sampling, being undetectable in over $90 \%$ of the plots with mean value of $0.55 \mathrm{mg} / \mathrm{L}$ (Table 2).

\subsection{Geostatistical analysis.}

Most variables were approximately normally distributed with a low skewness $(<1)$ (Table 2). Exceptions were soil available phosphate and magnesium and weed density in all fields and soil available potassium in T32, which were each positively skewed. Acceptable skewness values (0.03 to 0.75) were achieved for the soil nutrients after logarithmic transformation (Table 2).

The significant spatial variation occurring in most variables was bounded and accounted for by the sampling scheme in each field since most variograms reached a sill, becoming slightly flat over longer lag distances (Suppl. Figs S1-S3). The spatial variability in root yield and yield value was best accounted for by the circular model in all three fields and the exponential model best described the spatial variation in amino acid content of the beet (Suppl. Table S1). By contrast the spatial dependency and variability in sugar concentration was low such that the variogram appeared as pure nugget in T32 and WO3 (Suppl. Table S1, Suppl. Figs S1-S3). Soil available potassium was also pure nugget in White Patch and WO3, which, in this case, can be attributed to large and apparently random changes in available potassium over short distances. In general, however, most of the observed 
variation was spatially correlated, and the calculated spatial dependency was strong or moderate, ranging from 0 to $71 \%, 12$ to $49 \%$ and 14 to $63 \%$ in White Patch, T32 and WO3, respectively (Table 2: the lower the value, the greater the spatial dependency). Spatial dependence in yield value was very strong in White Patch (0\%: nugget variance of zero), and moderate in T32 (38\%) and WO3 (35\%) (Table 2, Suppl. Figs S1K-S3K).

The distance over which variation is spatially dependent, quantified by the range parameter and differed between fields and variables, being $64 \mathrm{~m}$ for soil moisture but $220 \mathrm{~m}$ for soil available magnesium in White Patch, and varying from 93 to $380 \mathrm{~m}$ in T32 and from 44 to $208 \mathrm{~m}$ in WO3 (Suppl. Table 1). 
Table 2: Summary statistics for the crop and environmental variables in all three fields. The canopy temperature is the average for the growing season (Table 1) Spatial dependency is the ratio of nugget: sill expressed as a percentage; the lower the value, the greater the spatial dependence.

\begin{tabular}{|c|c|c|c|c|c|c|c|c|c|c|c|c|c|c|c|}
\hline \multirow[b]{2}{*}{ Variables } & \multicolumn{5}{|c|}{ White Patch, 2012} & \multicolumn{5}{|c|}{$\underline{T 32,2012}$} & \multicolumn{5}{|c|}{$\underline{\text { WO3, } 2013}$} \\
\hline & Mean & Range & CV\% & $\begin{array}{l}\text { Skew- } \\
\text { ness }\end{array}$ & $\begin{array}{l}\text { Spatial } \\
\text { depend- } \\
\text { ency, \% }\end{array}$ & Mean & Range & CV\% & $\begin{array}{l}\text { Skew- } \\
\text { ness }\end{array}$ & $\begin{array}{l}\text { Spatial } \\
\text { depend- } \\
\text { ency, \% }\end{array}$ & Mean & Range & CV\% & $\begin{array}{l}\text { Skew- } \\
\text { ness }\end{array}$ & $\begin{array}{l}\text { Spatial } \\
\text { depend- } \\
\text { ency, \% }\end{array}$ \\
\hline Clay, \% & 28.6 & 21 & 19.8 & 0.03 & 0 & 20.8 & 13 & 13.6 & 0.18 & 22 & 40 & 22 & 11.6 & 0.32 & 46 \\
\hline Sand, \% & 67 & 29 & 10.5 & -0.05 & 11 & 74 & 15 & 4.7 & -0.28 & 48 & 52.6 & 30 & 10.5 & -0.29 & 41 \\
\hline Soil organic matter, \% & 3.4 & 3.1 & 15.1 & 0.47 & 31 & 3.4 & 2.2 & 11.9 & 0.03 & 39 & 4.3 & 3.2 & 13 & 0.62 & 45 \\
\hline Soil pH & 8.4 & 1.2 & 3.6 & -0.22 & 0 & 7.5 & 2.1 & 5.7 & -0.57 & 29 & 7.8 & 0.9 & 2 & 0.03 & 41 \\
\hline Soil electrical conductivity, $\mu S$ & 116.8 & 90 & 16.9 & -0.24 & 23 & 92.9 & 110 & 28.5 & 0.38 & 45 & 235 & 120 & 9.3 & 0.13 & 63 \\
\hline Soil moisture in June, \% & 36.7 & 33 & 16.8 & 0.04 & 20 & 28 & 25 & 18.6 & 0.005 & 37 & 27 & 23 & 22.3 & 0.26 & 14 \\
\hline Soil moisture in July, \% & 53 & 24 & 8 & 0.5 & 26 & 41 & 22 & 12.2 & 0.15 & 13 & 22 & 24 & 25 & -0.15 & 16 \\
\hline Soil moisture in August, \% & 24 & 25 & 20.3 & 0.57 & 7 & 19 & 20 & 27 & -0.54 & 12 & 20 & 14 & 14.6 & -0.13 & 27 \\
\hline Soil magnesium, mg/L & 24.6 & 143 & 136 & 1.8 & $\mathrm{Na}$ & 8.4 & 64 & 132 & 2.7 & $\mathrm{Na}$ & 16 & 62 & 76 & 1.54 & $\mathrm{Na}$ \\
\hline Soil log magnesium, mg/L & 1 & 1.8 & 59 & 0.43 & 71 & 1.6 & 4.2 & 65 & 0.41 & 42 & 2.5 & 3.2 & 30.3 & -0.09 & 60 \\
\hline Soil phosphate, $\mathrm{mg} / \mathrm{L}$ & 3.4 & 11 & 88.5 & 1.57 & $\mathrm{Na}$ & 8.9 & 37 & 106 & 1.22 & $\mathrm{Na}$ & 0.55 & 13 & 356 & 4.6 & $\mathrm{Na}$ \\
\hline Soil log phosphate, $\mathrm{mg} / \mathrm{L}$ & 0.93 & 2.5 & 78 & 0.75 & 43 & 1.56 & 3.64 & 78 & 0.03 & 38 & 232 & 440 & 63 & 0.43 & $\mathrm{Na}$ \\
\hline Soil potassium, mg/L & 330 & 417 & 39.3 & -0.6 & $\mathrm{Na}$ & 185 & 300 & 38.4 & 1.22 & $\mathrm{Na}$ & $\mathrm{Na}$ & $\mathrm{Na}$ & $\mathrm{Na}$ & $\mathrm{Na}$ & $\mathrm{Na}$ \\
\hline Soil log potassium, mg/L & $\mathrm{Na}$ & $\mathrm{Na}$ & $\mathrm{Na}$ & $\mathrm{Na}$ & $\mathrm{Na}$ & 2.24 & 0.7 & 6.8 & 0.48 & 48 & $\mathrm{Na}$ & $\mathrm{Na}$ & $\mathrm{Na}$ & $\mathrm{Na}$ & $\mathrm{Na}$ \\
\hline Seasonal incident radiation, $\mathrm{J} / \mathrm{m}^{2}$ & 1404 & 298 & 3.5 & -0.011 & 54 & 1332 & 171 & 2.5 & -0.23 & 52 & 1773 & 413 & 3.9 & -0.13 & 16 \\
\hline Mean canopy temperature, ${ }^{\circ} \mathbf{C}$ & 16.6 & 3.7 & 1.03 & 0.53 & $\mathrm{Na}$ & 16.2 & 3.1 & 4.4 & 0.51 & $\mathrm{Na}$ & 14.6 & 2.2 & 2.5 & 0.55 & $\mathrm{Na}$ \\
\hline Min canopy temperature, ${ }^{\circ} \mathbf{C}$ & 12 & 2.1 & 2.7 & 0.95 & $\mathrm{Na}$ & 12.2 & 1.7 & 3.0 & 0.15 & $\mathrm{Na}$ & 9.1 & 1.4 & 3.1 & 0.02 & $\mathrm{Na}$ \\
\hline Max canopy temperature, ${ }^{\circ} \mathbf{C}$ & 23 & 9.5 & 7.9 & 0.65 & $\mathrm{Na}$ & 21.7 & 7.7 & 6.3 & 0.28 & $\mathrm{Na}$ & 21.4 & 6.9 & 4.3 & 0.3 & $\mathrm{Na}$ \\
\hline Weed density $/ \mathbf{m}^{2}$ & 2.6 & 22 & 165 & 3.3 & $\mathrm{Na}$ & 0.58 & 3.2 & 106 & 1.98 & $\mathrm{Na}$ & 1.05 & 7.8 & 136.5 & 2.45 & $\mathrm{Na}$ \\
\hline Crop plant population, $1000 \mathrm{~s} / \mathrm{ha}$ & 91 & 49.8 & 14.5 & 0.0 & 28 & 95 & 45 & 13.1 & -0.19 & 49 & 50.8 & 59 & 20.9 & -0.05 & 24 \\
\hline Root yield, $t / h a$ & 58.4 & 53 & 21.2 & 0.47 & 0 & 75.7 & 42 & 11 & -0.04 & 42 & 68 & 111 & 31.6 & -0.59 & 36 \\
\hline Sugar, \% & 17.7 & 2.4 & 2.4 & -0.13 & 42 & 18.3 & 1.5 & 1.7 & -0.02 & $\mathrm{Na}$ & 16.2 & 2.3 & 2.2 & 0.22 & $\mathrm{Na}$ \\
\hline Yield value, $\mathfrak{f} / \mathrm{ha}$ & 1850 & 1870 & 21.3 & 0.41 & 5 & 2500 & 1450 & 11.3 & 0.05 & 46 & 1870 & 2897 & 32.0 & -0.63 & 37 \\
\hline Amino acid, $\mathrm{mg} / 100 \mathrm{~g}$ beet & 6.45 & 9 & 29.3 & 0.87 & 55 & 6.2 & 6 & 21.9 & 0.54 & 45 & 14.8 & 11 & 15.9 & 0.53 & 26 \\
\hline Potassium, $\mathrm{mg} / 100 \mathrm{~g}$ beet & 110 & 55 & 9 & 0.71 & 50 & 121 & 43 & 7.2 & 0.28 & 25 & 127 & 63 & 10.8 & 0.56 & 45 \\
\hline
\end{tabular}

Na: no data available or not applicable 
The Kriged maps show low and high yielding zones in each field. In White Patch, the most productive areas with yield value above the average of $£ 1850$ per ha were in the west of the field and extended toward the north-east, while the less productive areas were mainly in the south-east and extended to the middle with a small patch on the north side (Fig. 3 I). In T32, above average yields occurred in the south east extending towards the middle (Fig. 4 I). In WO3, yield values varied by an order of magnitude, being higher in the south-west extending northwards, while the south east corner was the least productive (Fig. 5 I).

\subsection{Correlations and redundancy analyses.}

Comparing the yield maps with the maps of other variables indicates some possible associations (Figs 3-5). Corroboration of both positive and negative correlations at field level is provided by Pearson correlation coefficients and the Redundancy Analyses (RDA) (Tables 3 and 4; Suppl. Table S2). In the RDA, the first two axes accounted for 60.9 and $54.6 \%$ of the variation in White Patch and T32, respectively $(P<0.01)$, but only the first axis was significant in WO3 (Table 3, Fig. 6). Variables, which were consistently and significantly $(P<0.05)$ correlated with root yield and which were statistically significant in the RDA (Table 4, Fig. 6), include plant population density, soil organic matter and soil moisture content (compare Figs 3-5 H with Figs 3-5 G, C and F; Fig. 6) with correlation coefficients ranging from 0.33 to 0.72 (Suppl. Table 2). High yielding areas of all fields were, however, always negatively correlated with seasonal incident solar radiation, weed density and mean seasonal canopy temperature (compare Figs. 3-5 H, with E, L and M, and Fig. 6) with correlation coefficients of -0.10 to -0.56 (Suppl. Table S2).

Other associations were inconsistent from field to field. For example, in White Patch, higher root yields occurred in the most clayey areas (Fig. $3 \mathrm{~A}, \mathrm{H}$ ), whereas clay was associated with lower root yields in WO3 (Fig. 5 A, H) with correlation coefficients of 0.36 and -0.26 , respectively (Suppl. Table S2). In T32, there was no clear visual association between the maps of root yield and soil clay content, but areas with a higher percentage of sand tended to be lower yielding (Fig. $4 \mathrm{~B}, \mathrm{H}$ ) with an overall correlation coefficient of -0.27 (Suppl. Table S2). Topographically, inconsistent relationships 
occurred with elevation, the low yielding areas of WO3 being in the highest parts of the field, whereas in White Patch and T32, the lowest yields were in the lowest parts of these fields (compare Figs 2 A-C with Figs 3-5 H). Slope and aspect were, however, never spatially associated with root yield (Fig. 6). Although relationships with elevation and soil type were inconsistent between fields, they were significant in the RDA ( $P=0.05$; Fig. 6 , Table 4). Soil $\mathrm{pH}$ and EC also showed inconsistent and weak visual spatial associations with root yield (Figs 3-5 G; Suppl. Figs 4-6), as did soil available magnesium (Figs 3-5 G, D) accounting for some variation in White Patch and WO3 ( $P \leq$ 0.05; Table 4, Fig. 6).

Although most variables had significant independent associations with the response variables, the RDA stepwise analysis identified only a few variables, whose partial effects on the explained variation were statistically significant ( $P \leq 0.05$; Table 4$)$. Of these, plant population density, soil clay, organic matter and moisture content, weed density, elevation and canopy temperature had significant partial effects in more than one field (Table 4). Perhaps the most important explanatory variable was the sugar beet plant population density, which was correlated with root yield, soil organic matter and soil moisture content in each field (Figs 3-5 and Fig. 6). This association was greatest in WO3 (Fig. 6 C) where plant population density accounted for $40.1 \%$ of the variation in response variables (Table 4) compared to 18.9 and $17.6 \%$ in White Patch and T32, respectively (Table 4).

Sugar beet quality variables (i.e. root content of sugar, amino acids and potassium) were closely related to each other in White Patch, but almost unrelated to the root yield (Fig. 6 A), while in T32, higher root yields were associated with higher root content of amino acids, but lower concentrations of potassium and sugar (Fig. 6 B). 


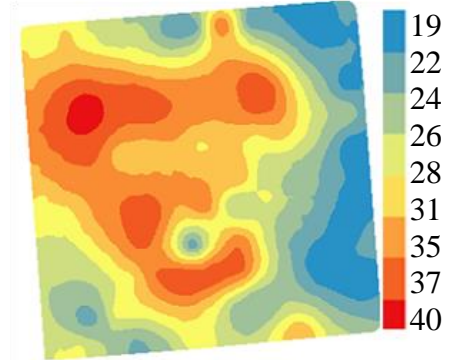

A. Clay, $\%$

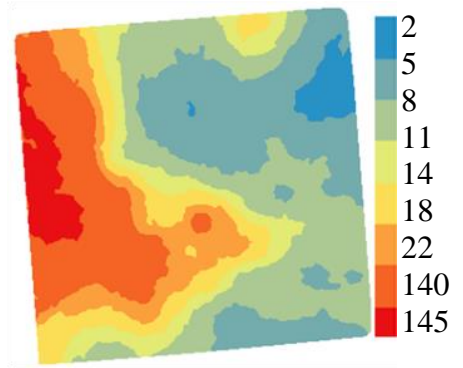

D. Soil available $\mathrm{Mg}, \mathrm{mg} / \mathrm{L}$

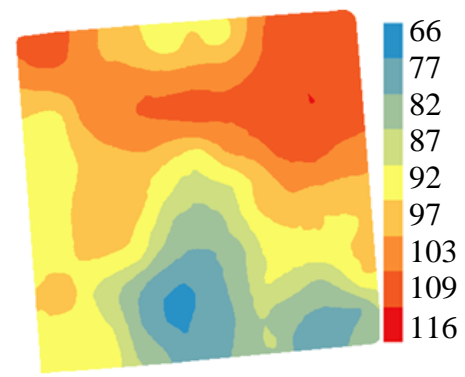

G. Plant population, 1000 plants/ha

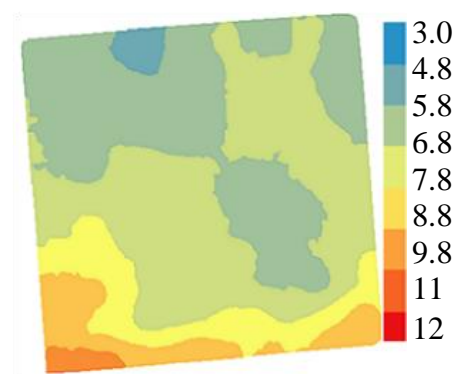

J. Amino acid, $\mathrm{mg} / 100 \mathrm{~g}$ beet

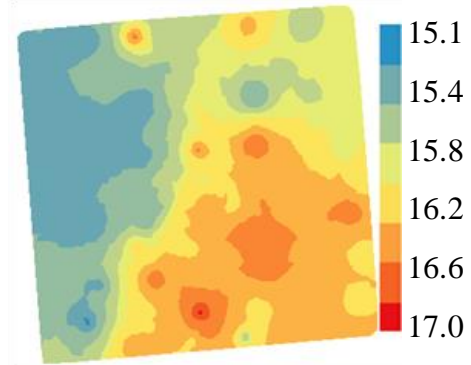

M. Mean canopy temperature, ${ }^{\circ} \mathrm{C}$

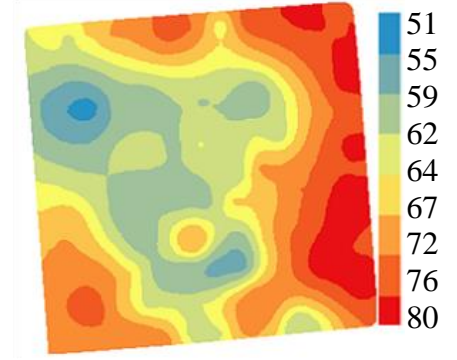

B. Sand, $\%$

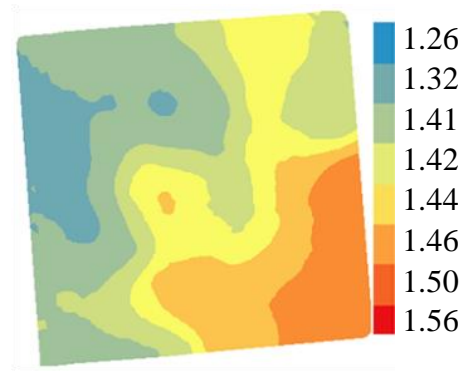

E. Incident solar radiation, $1000 \mathrm{~J} / \mathrm{m}^{2}$

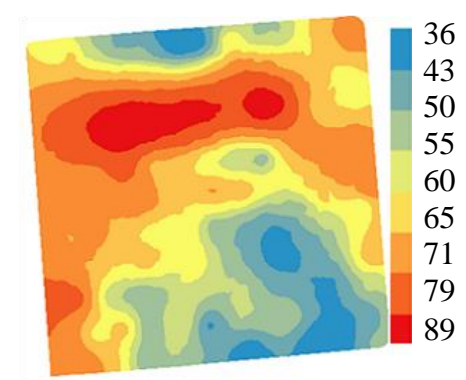

H. Root yield, t/ha

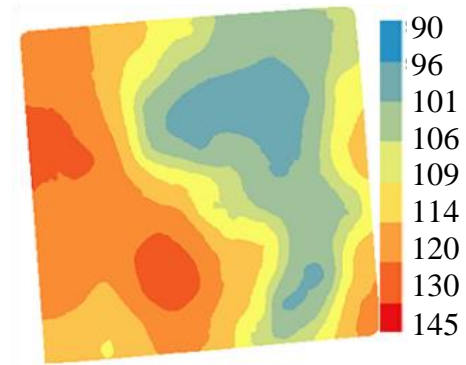

K. Potassium, mg/100g beet

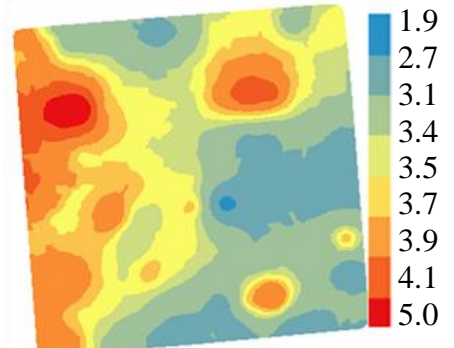

C. Organic matter, $\%$

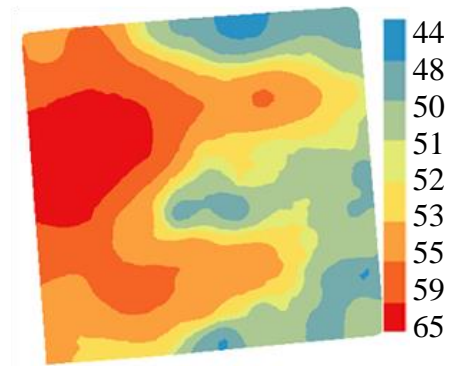

F. Soil moisture in July, \%

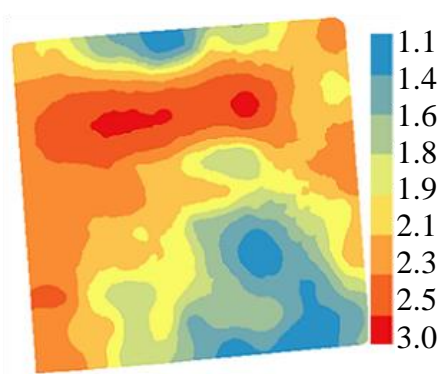

I. Yield value, $1000 £ / \mathrm{ha}$

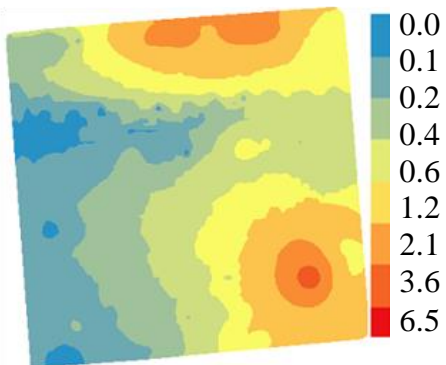

L. Weed density $/ \mathrm{m}^{2}$

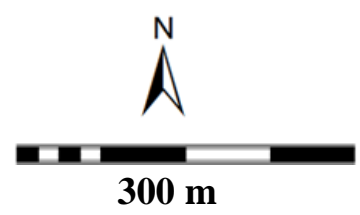

Figure 3: Interpolation maps of sugar beet yield, quality and some potential explanatory pedo-climatic-

biotic variables in White Patch field in 2012. 


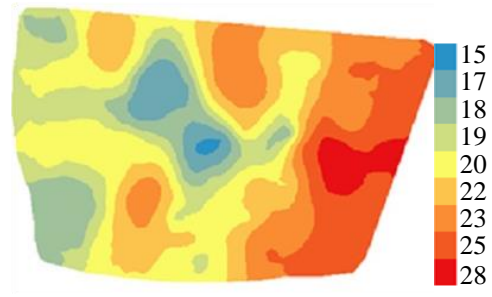

A. Clay, $\%$

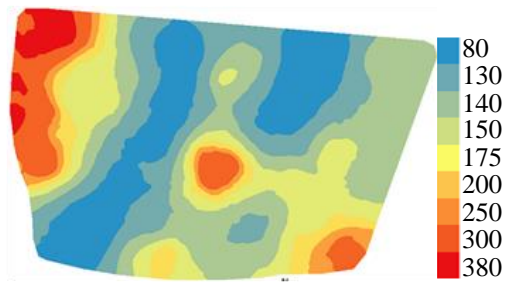

D. Soil available $\mathrm{Mg}, \mathrm{mg} / \mathrm{L}$

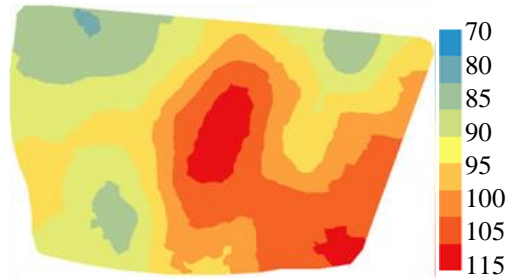

G. Plant population, 1000 plant/ha

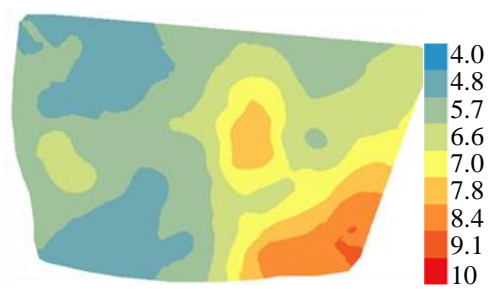

J. Amino acid, $\mathrm{mg} / 100 \mathrm{~g}$ beet

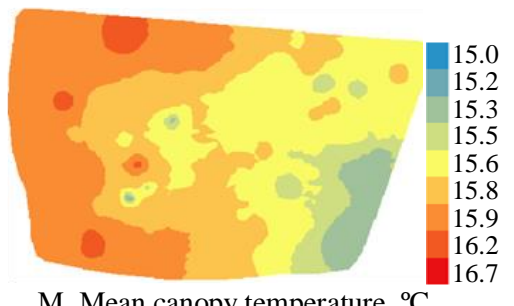

M. Mean canopy temperature, ${ }^{\circ} \mathrm{C}$

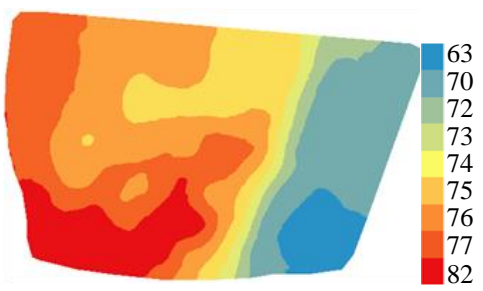

B. Sand, \%

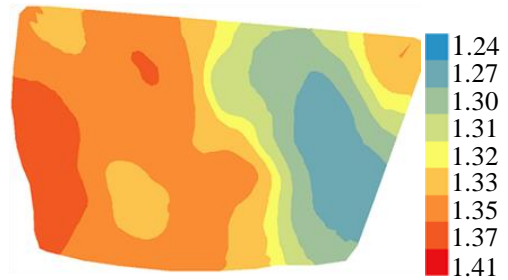

E. Incident solar radiation, $1000 \mathrm{~J} / \mathrm{m}^{2}$

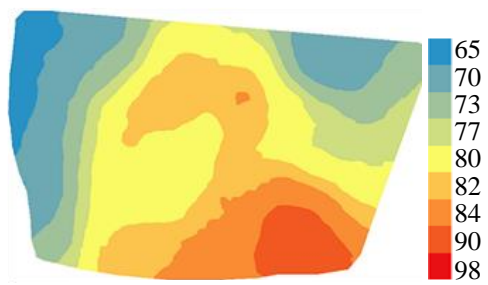

H. Root yield, tha

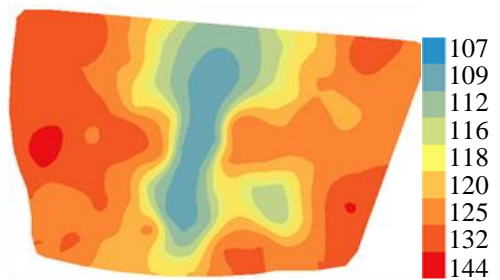

K. Potassium, $\mathrm{mg} / 100 \mathrm{~g}$ beet

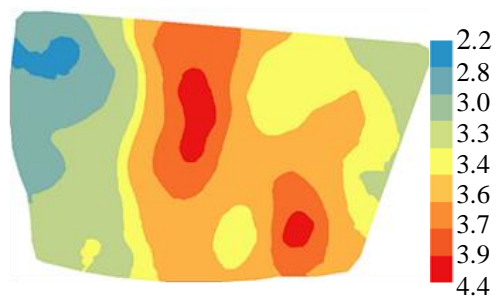

C. Organic matter, $\%$

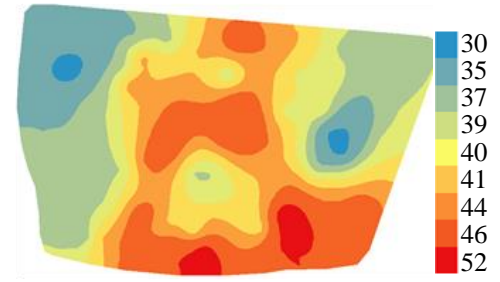

F. Soil moisture in July, \%

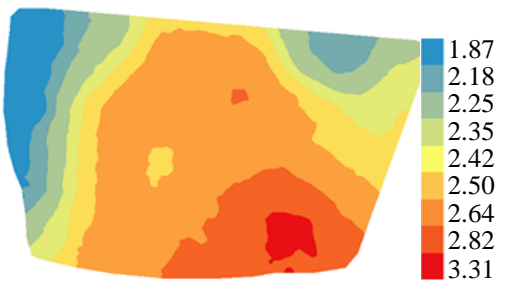

I. Yield value, $\mathfrak{f} / \mathrm{ha}$

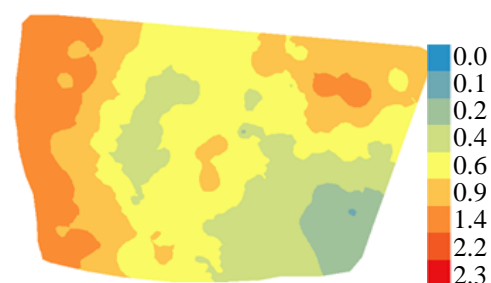

L. Weed density $/ \mathrm{m}^{2}$

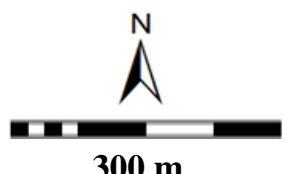

$300 \mathrm{~m}$

Figure 4: Interpolation maps of sugar beet yield, quality and some potential explanatory pedoclimatic-biotic variables in T32 in 2012. 


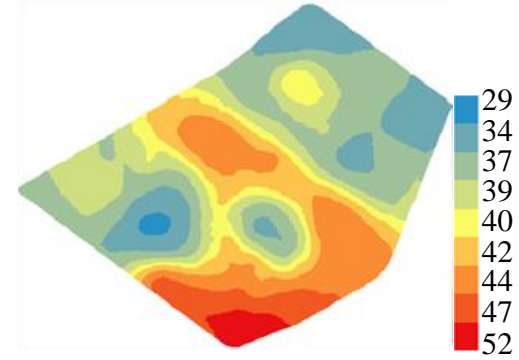

A. Clay, $\%$

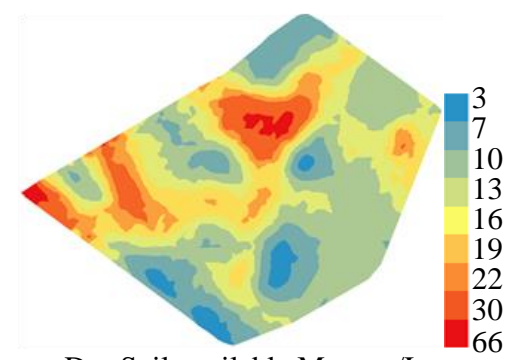

D. Soil available $\mathrm{Mg}, \mathrm{mg} / \mathrm{L}$

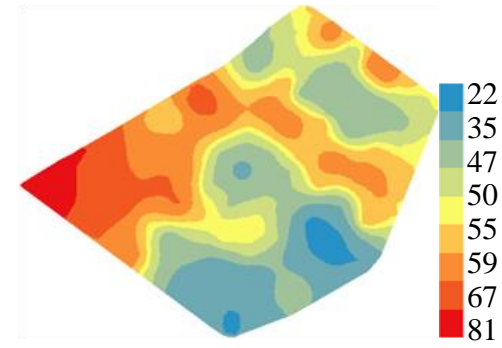

G. Plant population, 1000 plant/ha

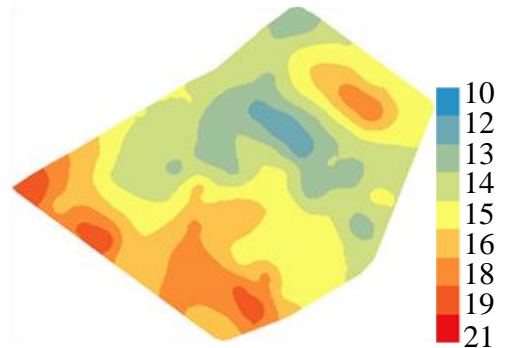

J. Amino acid, mg/100g beet

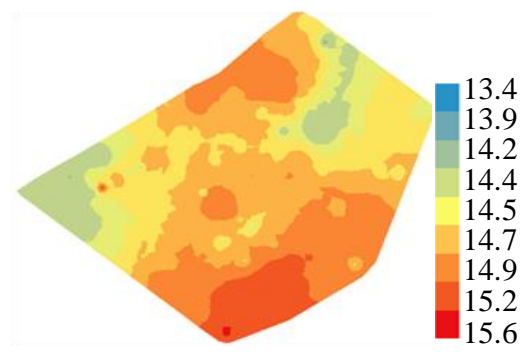

M. Mean canopy temperature, ${ }^{\circ} \mathrm{C}$

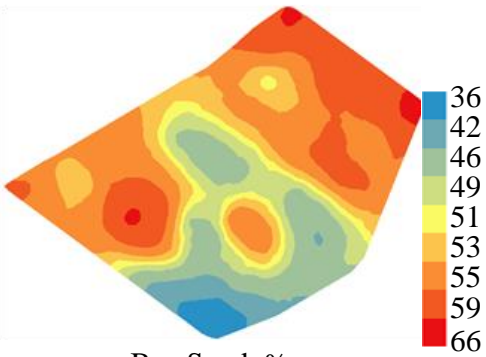

B. Sand, \%

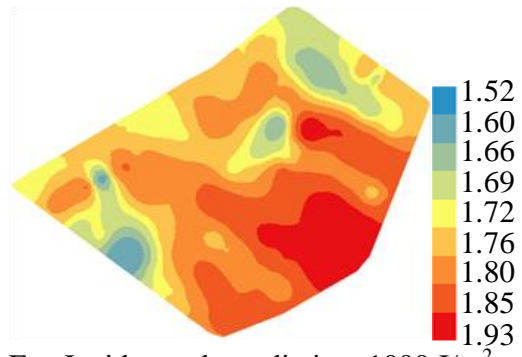

E. Incident solar radiation, $1000 \mathrm{~J} / \mathrm{m}^{2}$

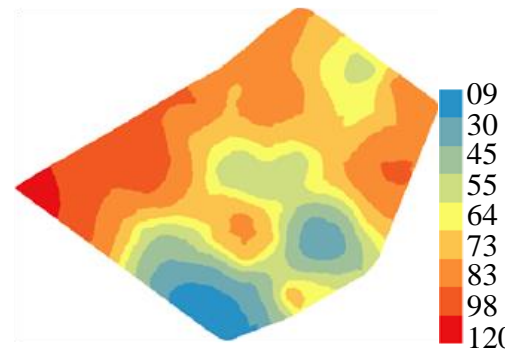

H. Root yield $\mathrm{t} / \mathrm{ha}$

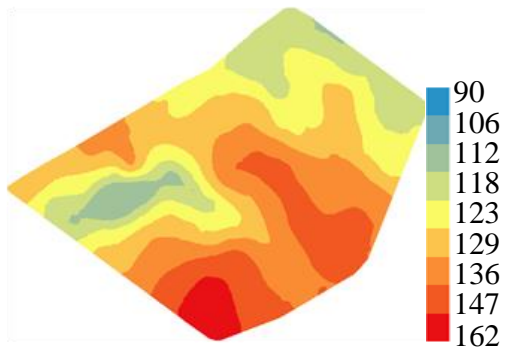

K. Potassium, mg/100g beet

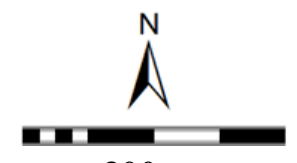

$300 \mathrm{~m}$

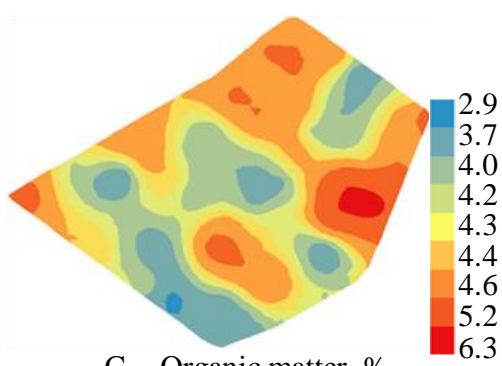

C. Organic matter, $\%$

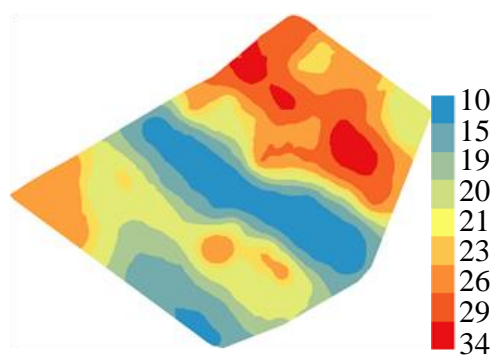

F. Soil moisture in July, \%

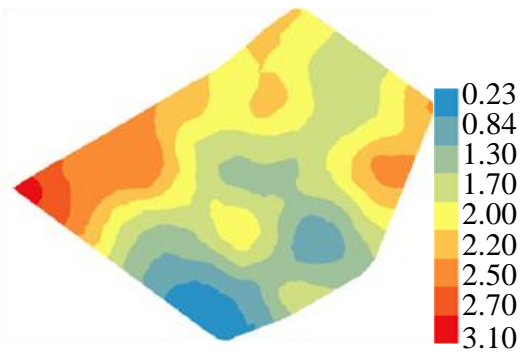

I. Yield value $£ / h$

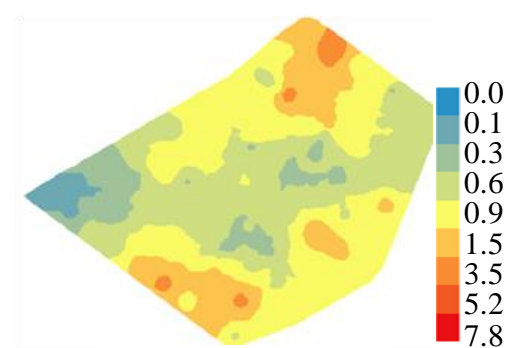

L. Weed density $/ \mathrm{m}^{2}$

Figure 5: Interpolation maps of sugar beet yield, quality and some potential explanatory pedoclimatic-biotic variables in WO3 in 2012. 
Table 3: Summary statistics of the Redundancy Analyses for the first four axes in each field.

\begin{tabular}{|c|c|c|c|c|}
\hline Field & Axis 1 & Axis 2 & Axis 3 & Axis 4 \\
\hline \multicolumn{5}{|l|}{ White Patch } \\
\hline Eigenvalues & 0.467 & 0.14 & 0.0001 & 0.0001 \\
\hline Explained variation & 46.7 & 60.9 & 61.0 & 61.0 \\
\hline$P$ value & 0.002 & 0.008 & 1 & 1 \\
\hline \multicolumn{5}{|l|}{ T32 } \\
\hline Eigenvalues & 0.399 & 0.146 & 0.0037 & 0.0001 \\
\hline Explained variation & 40.0 & 54.6 & 55.0 & 55.0 \\
\hline$P$ value & 0.002 & 0.03 & 1 & 1 \\
\hline \multicolumn{5}{|l|}{ WO3 } \\
\hline Eigenvalues & 0.558 & 0.061 & 0.0013 & 0 \\
\hline Explained variation & 55.8 & 61.9 & 62.1 & 62.1 \\
\hline$P$ value & 0.002 & 0.064 & 1 & 1 \\
\hline
\end{tabular}


Table 4: Results of Redundancy Analyses showing A) independent and B) partial effects of the explanatory pedo-climatic-biotic variables on the percentage variance of the response variables (yield, sugar, amino acid and potassium content of beet) accounted for in the three fields. Results are ordered by the variance accounted for as independent variables in White Patch. Abbreviations in brackets are used in Fig. 6.

\begin{tabular}{|c|c|c|c|c|c|c|}
\hline \multirow{2}{*}{$\begin{array}{l}\text { A } \\
\text { Explanatory variable }\end{array}$} & \multicolumn{2}{|c|}{ White Patch } & \multicolumn{2}{|c|}{$\underline{\mathrm{T} 32}$} & \multicolumn{2}{|c|}{$\underline{\mathrm{WO} 3}$} \\
\hline & $\%$ variance & $P$ & $\%$ variance & $P$ & $\%$ variance & $P$ \\
\hline Weed density $/ \mathrm{m}^{2}$ (Weeds) & 26.6 & 0.002 & 12.6 & 0.002 & 6.2 & 0.002 \\
\hline Plant population density per ha (PP) & 18.9 & 0.002 & 17.6 & 0.002 & 40.1 & 0.002 \\
\hline Max canopy temperature, ${ }^{\circ} \mathrm{C}(\mathbf{T m a x})$ & 18.7 & 0.002 & 3.0 & 0.064 & 7.4 & 0.002 \\
\hline Soil organic matter, \% (SOM) & 16.4 & 0.002 & 20.2 & 0.002 & 7.9 & 0.002 \\
\hline Soil moisture content, \% (SMC) & 11.7 & 0.002 & 5.4 & 0.08 & 27.7 & 0.002 \\
\hline Clay, $\%$ & 9.6 & 0.002 & 2.6 & 0.12 & 12.2 & 0.002 \\
\hline Mean canopy temperature, ${ }^{\circ} \mathrm{C}(\mathbf{T})$ & 7.4 & 0.002 & 1.2 & 0.32 & 4.8 & 0.012 \\
\hline Sand, $\%$ & 6.3 & 0.01 & 3.1 & 0.072 & 15.4 & 0.002 \\
\hline Radiation, $\mathrm{J} / \mathrm{m}^{2}$ & 5.3 & 0.016 & 0.8 & 0.49 & 2.8 & 0.056 \\
\hline Elevation, $\mathrm{m}$ & 4.1 & 0.022 & 1.8 & 0.20 & 26.1 & 0.002 \\
\hline Available magnesium, mg/L (Mg) & 4.0 & 0.034 & 0.7 & 0.52 & 8.1 & 0.002 \\
\hline Slope, $\%$ & 3.3 & 0.03 & 1.1 & 0.38 & 0.5 & 0.48 \\
\hline Available potassium, mg/L (K) & 1.8 & 0.0 .2 & 1.4 & 0.27 & 0.2 & 0.72 \\
\hline Min canopy temperature, ${ }^{\circ} \mathrm{C}(\mathbf{T m i n})$ & 1.2 & 0.37 & 1.0 & 0.42 & 6.1 & 0.006 \\
\hline Aspect, ${ }^{\circ}$ & 0.8 & 0.52 & 0.2 & 0.87 & 0.8 & 0.42 \\
\hline Available phosphate, mg/L (P) & 0.8 & 0.48 & 0.5 & 0.66 & 0.7 & 0.38 \\
\hline Electrical conductivity, $\mu \mathrm{S}(\mathbf{E C})$ & 0.5 & 0.63 & 1.2 & 0.34 & 0.6 & 0.50 \\
\hline $\mathrm{pH}$ & 0.2 & 0.88 & 4.0 & 0.038 & 1.0 & 0.34 \\
\hline \multicolumn{7}{|l|}{ B } \\
\hline Weed density $/ \mathrm{m}^{2}$ & 26.6 & 0.002 & 10.6 & 0.002 & 1.2 & 0.066 \\
\hline Plant population density per ha & 11 & 0.002 & 6.6 & 0.002 & 40.1 & 0.002 \\
\hline Max canopy temperature, ${ }^{\circ} \mathrm{C}$ & 1.3 & 0.082 & 0.9 & 0.23 & 0.7 & 0.17 \\
\hline Soil organic matter, $\%$ & 2.5 & 0.028 & 20.2 & 0.002 & 1.7 & 0.018 \\
\hline Soil moisture content, $\%$ & 7.8 & 0.002 & 0.8 & 0.30 & 9.2 & 0.002 \\
\hline Clay, $\%$ & 1.2 & 0.15 & 0.6 & 0.47 & 1.6 & 0.034 \\
\hline Mean canopy temperature, ${ }^{\circ} \mathrm{C}$ & 1.1 & 0.15 & 1.1 & 0.18 & 0.2 & 0.53 \\
\hline Sand, $\%$ & 0.2 & 0.68 & 2.8 & 0.02 & 0.3 & 0.55 \\
\hline Radiation, $\mathrm{J} / \mathrm{m}^{2}$ & 0.8 & 0.21 & 0.9 & 0.25 & 0.2 & 0.56 \\
\hline Elevation, $\mathrm{m}$ & 1.3 & 0.08 & 2.8 & 0.026 & 2.7 & 0.002 \\
\hline Available magnesium, mg/L & 2.4 & 0.01 & 0.1 & 0.19 & 1.2 & 0.048 \\
\hline Slope, $\%$ & 0.4 & 0.40 & 0.5 & 0.47 & 0.2 & 0.53 \\
\hline Available potassium, mg/L & 0.1 & 0.75 & 0.3 & 0.66 & 0.4 & 0.31 \\
\hline Min canopy temperature, ${ }^{\circ} \mathrm{C}$ & 1.1 & 0.14 & 0.7 & 0.33 & 0.5 & 0.32 \\
\hline Aspect, ${ }^{\circ}$ & 0.7 & 0.25 & 0.3 & 0.68 & 0.2 & 0.52 \\
\hline Available phosphate, mg/L & 1.4 & 0.10 & 0.4 & 0.57 & 0.6 & 0.26 \\
\hline Electrical conductivity, $\mu \mathrm{S}$ & 0.4 & 0.50 & 0.1 & 0.91 & 0.1 & 0.74 \\
\hline $\mathrm{pH}$ & 0.6 & 0.30 & 1.5 & 0.09 & 0.9 & 0.11 \\
\hline
\end{tabular}



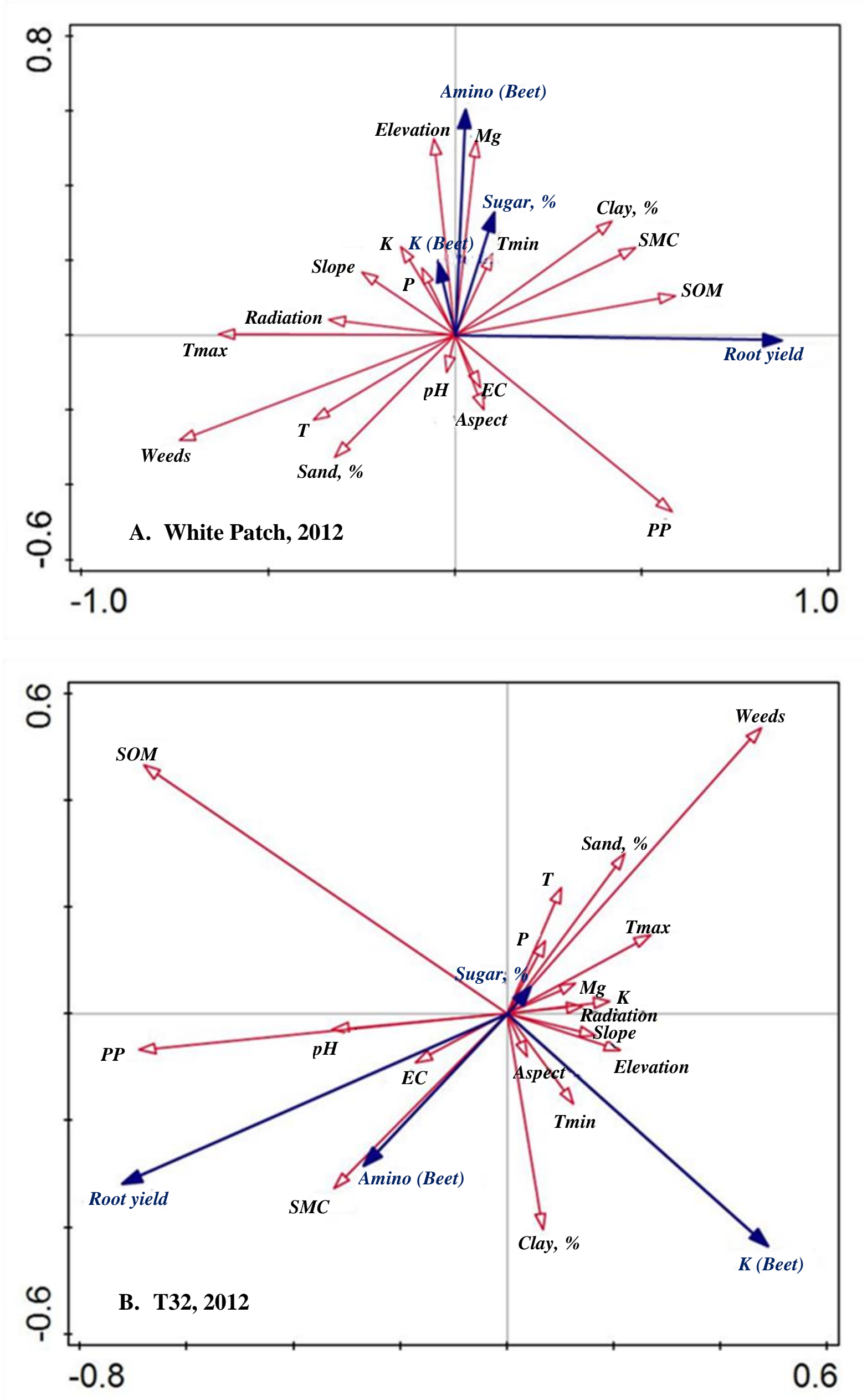


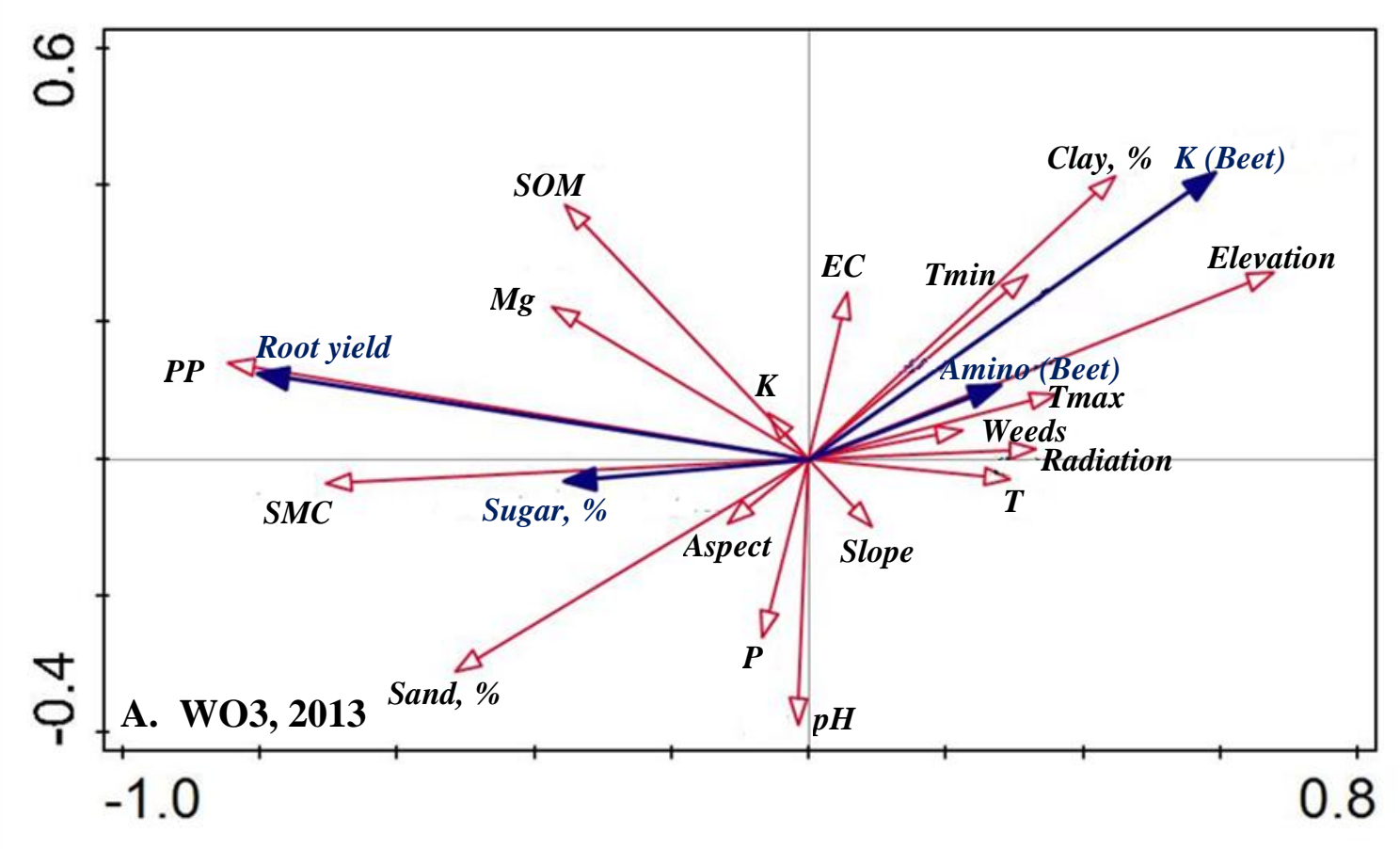

Figure 6: Ordination biplots based on redundancy analyses of the sugar beet root yield and quality as response variables (solid blue arrows) with pedo-climatic-biotic explanatory variables (open red arrows) in A) White Patch, B) T32 and C) WO3. See Table 4 for abbreviations used for explanatory variables. Potassium in beet is shown as $K$ (Beet) and amino acid content as Amino (Beet).

\section{Discussion}

\subsection{Variograms.}

The variograms for most variables were almost isotropic, indicating similar patterns of variation in all directions and the semi-variances were mainly a function of lag distances (Piccini et al., 2014). Since the variograms for most variables reached a sill, the spatial variation throughout each field was patchy and could mostly be accounted for by the sampling scheme for each field. The nugget variance was, however, high for some variables in T32, which could be the unresolved variation due to the longer sampling intervals in this than in the other two fields (Table 1) or it could be measurement error (Webster and Oliver, 2007, Oliver, 2010). Such explanations do not account for high nugget variance for root yield and yield value in WO3 where yield sometimes varied erratically over short distances, such that some plots had to be extended to provide enough roots for analysis. 


\subsection{Spatial variability in the economic yield of sugar beet.}

This paper is the first to provide yield maps for sugar beet and it is clear that economically significant spatial variability in yield existed in each field. Even in T32 - the most uniform of the three fields assessed, yield values still varied from $£ 1870$ to $£ 3320$ per ha. With hindsight the south corner of WO3, which returned a yield value of $£ 230$ per ha was probably not worth planting. The reasons for this variability clearly merit further discussion and testing.

\subsection{Potential biotic constraints on the economic yield of sugar beet.}

Crop and weed population densities - were identified as key potential driving variables of sugar beet yield and quality variation in the RDA in all three fields. Plant population density was positively while weed density was negatively correlated with root yield in all fields. In WO3 in particular, the mean plant population density (51000/ha) was only half that recommended for maximum yield and even the highest among the 114 sampling locations (81000/ha) only just exceeded Jaggard et al.'s (2011) economic optimum of 80000/ha. Reporting older research from 1967, Jaggard and Qi (2006) stated that "on mineral soils a population of 75000/ha is the minimum required for maximum sugar yield". Moreover the asymptotic relationship of sugar yield to plant density means that most plots in WO3 were sub-optimal and increasingly severe yield penalties would be expected and were found as density decreased. A major reason for lower yield at low density is the decrease in solar radiation interception (Jaggard and Qi, 2006). Poor and very uneven crop establishment of sugar beet was reported in the 2013 season by many farmers in the East of England, particularly by those who planted their crops earlier than average (Stevens, 2013) and WO3 was one of the earliest crops sown in the UK. Stevens (2013) reported that the dry weather and much lower temperatures in 2013 were associated with slower emergence and large numbers of abnormal seedlings. The variability in plant establishment in WO3 was perhaps also exacerbated by relatively low soil moisture content and soil organic matter in areas of low plant population. Moreover, spatial variability in plant population was strongly and negatively associated with weed density suggesting that the areas of low plant 
population allowed more space for new weeds to emerge in summer and would be expected to result in greater weed competition (Kropff et al., 1992).

\subsection{Potential environmental constraints on the economic yield of sugar beet.}

Spatial variability in sugar beet yield was also associated with environmental variables. One of the likely driving variables for crop yield was soil moisture content, which was positively correlated with sugar yield in all three fields. Dry matter accumulation in sugar beet roots is known to be greatly affected by available soil moisture during July and August (Kenter et al., 2006). Jaggard et al. (1997) found that yields of sugar beet were lower in dry summers. The amount of water available under dry conditions depends on soil water holding capacity and soil hydraulic conductivity (Hakojärvi et al., 2013) which varies within and between fields. Soil water holding capacity and other soil physical, chemical and biological properties are themselves affected by another potential driving variable, namely soil organic matter (D'Hose et al., 2014), which was associated with root yields in White Patch and T32. Interestingly, yield was negatively related to canopy temperature in all three fields. The negative association between root yields and maximum canopy temperature in all three fields could be due to higher rates of respiration and evapotranspiration under higher canopy temperature (Draycott, 2008). The low yielding areas had lower soil moisture early in June and higher mean canopy temperatures indicating scope for site-specific irrigation early in the season.

Soil type showed different correlations from one field to another, perhaps due to the differences in weather conditions in 2012 and 2013. For example, sugar beet yield was positively related to soil clay content in White Patch and negatively related in WO3. This might be accounted for by poorer emergence of sugar beet in clayey soils, especially at the low temperature which occurred in March 2013 (mean temperature: $3.5^{\circ} \mathrm{C}$, Fig. 2, CEDA, 2014). As noted above, this cool weather affected emergence in WO3 and many early sown fields of sugar beet in the East of England (Stevens, 2013). With respect to soil type, the low yielding areas in T32 had a relatively high sand content. Field aspect and slope and hence the calculated incident solar radiation varied significantly across each field, but there were not significant association with sugar beet yield and quality, even though it was 
significantly associated with maximum canopy temperature, which might be expected to reduce sugar beet yield and quality (Kenter et al., 2006). Clearly both the amount of incident radiation and the efficiency of its use are important (Jaggard et al., 2009).

\subsection{Identifying the potential driving variables of sugar beet yield and quality using RDA.}

Different methods have been used to identify the environmental variables associated with yield variability. Zhu et al. (2013) produced a functional soil map in which soil properties were layered to identify those associated with the yields of corn and soybean. Liu et al. (2013) used factorial kriging with step-wise multiple regression analyses to detect association between soil attributes, while Simmonds et al. (2013) applied a regression tree to classify the underlying cause of the spatial variability in a rice yield. Here RDA was used to identify the key environmental variables efficiently, although the assumption that correlations applied similarly at different locations or spatial scales within each field needs to be tested (Metcalfe et al., 2016). The main merit of RDA, which distinguishes it from other methods, is that it can show how different explanatory variables relate to each other as well as to the response variables of sugar beet yield and quality. In the RDA, many variables were significantly associated with the response variables when considered independently, but few retained statistical significance when effects were combined. Some variables were therefore important predictors, but only if considered individually, since they could be explaining variability which has already accounted by other variables. Rodriguez-Moreno et al. (2014) stated that if two variables are strongly related to yield, it is expected that they will also be strongly related to each other, an example here being the visual association between soil type, soil moisture content and elevation. It appears that the spatial variability in sugar beet yield might, however, have resulted from the combined effects of several environmental and biotic variables, as each of these variables accounted for some of the variability in sugar beet yield and quality.

In addition, much variability was not accounted for in the RDA and this might relate to unassessed variables such as soil micro-nutrients, soil infiltration rate, and the diffusion of soil water and 
nutrients (Lark, 2012) or to management practices (Taylor et al., 2003), which all need to be investigated in future studies.

\subsection{Why is investigating the spatial variability important?}

It is therefore clear that mapping the spatial variability in sugar beet yield and identifying the main associated environmental variables highlights an incentive for farmers to manage sugar beet fields more precisely rather than uniformly as in the three fields studied. Irrigation, fertilization and weed control are obvious targets for precision farming, since these can be managed site-specifically using existing technology, providing geo-referenced maps are available. Soil organic matter, soil type and field topography are, however, difficult to manage. Spatially variable compost, manure or crop residue management and reduced tillage in areas of low soil organic matter at appropriate stages in crop rotation might, however, improve the soil biological, chemical and physical properties in those parts of the field (D'Hose et al., 2014). Less intensive cultivation and perhaps adoption of zero tillage for the combinable crops or strip tillage for crops like sugar beet could also help to mitigate soil moisture stress. Canopy temperature is also outside the grower's control, but the negative association between canopy temperature and soil moisture content might suggest irrigating the areas of higher canopy temperature to compensate the losses of soil water. Most importantly, however, the significance of poor emergence cannot be over-emphasised and redrilling patches with low emergence might have been justified.

Research is needed to validate these inferences and also to facilitate early predictions of within field variability. 


\section{Conclusions:}

1. Mapping sugar beet yields identified high and low yielding patches with final economic yields of sugar beet ranging from $£ 1120$ to $£ 2990, £ 1870$ to $£ 3320$ and $£ 230$ to $£ 3127$ per ha in the fields, White Patch, T32 and WO3, respectively.

2. In all three fields, root yield was highly and positively correlated to the plant population density and the spatial distribution of soil organic matter and soil moisture, but negatively correlated with weed density and canopy temperature (mean and maximum).

3. Redundancy Analysis (RDA) accounted for the separate and combined effects of biotic and environmental variables associated with the variability in sugar beet yield and quality. The results of RDA were supported by the visual association of variables in Kriging maps.

4. The variability observed suggests that uniform field management of sugar beet is likely to lead to sub-optimal use of inputs. Further research is needed to explore how soil moisture, nutrients and weeds might be managed site-specifically during the growing season to increase the crop productivity and value across the field and especially in low yielding areas.

5. An early prediction of spatial variability in sugar beet yield and its relation to the environment is needed, so that a spatially variable crop management can be applied to the sugar beet crop.

\section{Acknowledgments}

Our thanks to: the Kurdistan regional government for PhD scholarship to S.A.M.; Broom's Barn Research station (Mark Stevens and Andrew Creasy) and Trumpington Farm Company (David Knott) for access to fields, labs and transportation; British Sugar (Colin Walters) for facilitating sugar analysis; Liam Doherty, Caroline Hadley and Richard Casebow of Reading University for technical support; and Will Foss (Agrii), Margaret Oliver (Reading), Richard Webster (Rothamsted Research) for advice and support. 


\section{References}

CEDA 2014. Centre for environmental data archival: Web processing service (http://cedawps2.bdc.rl.ac/ui/home).

D’HOSE, T., COUGnON, M., DE VliEGHER, A., VANDECASTEELE, B., VIAENE, N., CORNELIS, W., VAN BOCKSTAELE, E. \& REHEUL, D. 2014. The positive relationship between soil quality and crop production: A case study on the effect of farm compost application. Applied Soil Ecology, 75, 189-198.

DRAYCOTT, A. P. 2008. Sugar beet, Oxford-UK, Wiley

EDDY, S. \& JOHNSTON, S. R. 2009. Comparison of Palintest soil analysis with external laboratory analysis. Sunderland UK, Palintest Ltd. Available online from https://www.yumpu.com/en/document/view/6548199/comparison-of-soil-test-methods-2009pdf-palintest. Accessed April 2017.

FRANZEN, D. 2004. Delineating nitrogen management zones in a sugar beet rotation using remote sensing - A Review. Journal of Sugar Beet Research, 41, 47-60.

GARTHWAITE, D.G., HUDSON, S., BARKER, I., PARRISH, G., SMITH, L. \& PIETRAVALLE S. 2013. Pesticide usage survey report 250, Arable crops in Great Britain 2012. York-UK, Food \& Environment Research Agency.

HAKOJÄRVI, M., HAUTALA, M., RISTOLAINEN, A. \& ALAKUKKU, L. 2013. Yield variation of spring cereals in relation to selected soil physical properties on three clay soil fields. European Journal of Agronomy, 49, 1-11.

HBIRKOU, C., WELP, G., REHBEIN, K., HILLNHÜTTER, C., DAUB, M., OLIVER, M. \& PÄTZOLD, S. 2011. The effect of soil heterogeneity on the spatial distribution of Heterodera schachtii within sugar beet fields. Applied Soil Ecology, 51, 25-34.

HEEGE, H. J. 2013. Precision in crop farming. In: HEEGE, H. J. (ed.) Site specific concepts and sensing methods: Applications and results, Heidelberg-Germany: Springer.

HOLLIDAY, R. 1960. Plant population and crop yield. Nature, 186, 22 - 24. 
JAGGARD, K. W. \& QI, A. (2006). Agronomy. In: DRAYCOTT, A. P. (ed.) Sugar beet, pp. 134168. Oxford-UK, Blackwell Publishing Ltd.

JAGGARD, K. W., ALISON, M. F, TODD, A. D. 1997. Nutrient availability and yield variation in beet rotation: implication for precision farming. Proceedings of the $60^{\text {th }}$ IIRB Congress, July 1997, Cambridge (UK).

JAGGARD, K. W., QI, A. \& OBER, E. 2009. Capture and use of solar radiation, water, and nitrogen by sugar beet (Beta vulgaris L.). Journal of Experimental Botany, 60, 1919.

JAGGARD, K. W., QI, A., MILFORD, G., CLARK, C., OBER, E., WALTERS, C. \& BURKS, E. 2011. Determining the optimal population density of sugar beet crops in England. International Sugar Journal, 113, 114-119.

JOHNSTON, K., VER HOEF, J. M., KRIVORUCHKO, K. \& LUCAS, N. 2001. Using ArcGIS geostatistical analyst, California-USA, ESRI Redlands.

JONES, H. \& SCHOFIELD, P. 2008. Thermal and other remote sensing of plants stress. General Applied Plant Physiology, 34,19-32.

JONES JR, J. B. 1999. Soil analysis handbook of reference methods, Boca Raton-USA, CRC Press

KARAMAN, M. R., SUSAM, T., ER, F., YAPRAK, S. \& KARKACIER, O. 2009a. Simulation of organic matter variability on a sugar beet field using the computer based geostatistical methods. Engineering and Technology, 56, 724-727.

KARAMAN, M. R., SUSAM, T., YAPRAK, S. \& ER, F. 2009b. Computer based geostatistical strategies in assessing of spatial variability of agricultural phosphorus on a sugar beet field. Proceedings International Conference of Information Management and Engineering. Kuala Lumpur. IEEE, pp. 201-204.

KENKEL, N., DERKSEN, D., THOMAS, A. \& WATSON, P. 2002. Review: Multivariate analysis in weed science research. Weed Science, 50, 281-292. 
KENTER, C., HOFFMANN, C. M. \& MARLANDER, B. 2006. Effects of weather variables on sugar beet yield development (Beta vulgaris L.). European Journal of Agronomy, 24, 62-69.

KROPFF, M.J., SPITTERS, C.J.T., SCHNIEDERS, B.J., JOENJE, W. \& GROOT, W. D. 1992. An eco-physiological model for interspecific competition, applied to the influence of Chenopodium album L. on sugar beet. II. Model evaluation. Weed Research, 32, 451-463.

KUMAR, L., SKIDMORE, A. K. \& KNOWLES, E. 1997. Modelling topographic variation in solar radiation in a GIS environment. International Journal of Geographical Information Science, $11,475-497$.

LARK, R. 2012. Towards soil geostatistics. Spatial Statistics, 1, 92-99.

LIU, Y., LV, J., ZHANG, B. \& BI, J. 2013. Spatial multi-scale variability of soil nutrients in relation to environmental factors in a typical agricultural region, Eastern China. Science of the Total Environment, 450, 108-119.

METCALFE, H., MILNE, A. E., WEBSTER, R., LARK, R. M., MURDOCH, A. J. \& STORKEY, J. 2016. Designing a sampling scheme to reveal correlations between weeds and soil properties at multiple spatial scales. Weed Research, 56, 1-13.

OLIVER, M., BISHOP, T. \& MARCHANT, B. 2013. Precision agriculture for sustainability and environmental protection, Abingdon, Oxon-UK, Routledge.

OLIVER, M. \& WEBSTER, R. 2014. A tutorial guide to geostatistics: Computing and modelling variograms and Kriging. Catena, 113, 56-69.

OLIVER, M. A. 2010. Geostatistical applications for precision agriculture, London-UK, Springer.

PAYNE, R. W. 2009. GenStat. Wiley Interdisciplinary Reviews: Computational Statistics, 1, 255258.

PEREIRA, G. T., SOUZA, Z. M. D., TEIXEIRA, D. D. B., MONTANARI, R. \& MARQUES JÚNIOR, J. 2013. Optimization of the sampling scheme for maps of physical and chemical properties estimated by Kriging. Revista Brasileira de Ciência do Solo, 37, 1128-1135. 
PICCINI, C., MARCHETTI, A. \& FRANCAVIGLIA, R. 2014. Estimation of soil organic matter by geostatistical methods: Use of auxiliary information in agricultural and environmental assessment. Ecological Indicators, 36, 301-314.

REYNOLDS, G. J. 2010. Remote Sensing for Detection of Rhizoctonia Crown and Root Rot in Sugar Beet and the Impact of the Disease on Chlorophyll Content. MSc. Thesis, University of Minnesota.

RICHTER, G., QI, A., SEMENOV, M. \& JAGGARD, K. 2006. Modelling the variability of UK sugar beet yields under climate change and husbandry adaptations. Soil Use and Management, 22, 39-47.

RODRIGUEZ-MORENO, F., LUKAS, V., NEUDERT, L. \& DRYŠLOVÁ, T. 2014. Spatial interpretation of plant parameters in winter wheat. Precision Agriculture, 15, 1-19.

SCANNAVINO, F. A., PEREZ-KUROKI, A. J., GHOBAKHLOU, A., SALliSC, P., SHANMUGANATHAN, S. \& CRUVINEL, P. E. 2011. Spatial variability on soil pH gradient: A case study in vineyards. In: CHAN, F., MARINOVA, D. \& ANDERSSEN, R.S. (eds) MODSIM 2011, 19th International Congress on Modelling and Simulation. Perth, Australia. December 2011, pp. 1139 - 1145. ISBN: 978-0-9872143-1-7.

SHELDRICK, B. H. \& WANG, C. 1993. Particle size distribution. In: CARTER, M. R. (ed.) Soil sampling and methods of analysis. Boca Raton-USA: CRC Press.

SIMMONDS, M. B., PLANT, R. E., PENA-BARRAGÁN, J. M., VAN KESSEL, C., HILL, J. \& LINQUIST, B. A. 2013. Underlying causes of yield spatial variability and potential for precision management in rice systems. Precision Agriculture, 14, 512-540.

ŠMILAUER, P. \& LEPŠ, J. 2014. Multivariate analysis of ecological data using CANOCO 5, Cambridge-UK, Cambridge University Press.

STEVENS, M. 2013. 2013 emergence issue. A review by the BBRO. In: LIMB, R. (ed.) British Sugar Beet Review, 81 (4), 13-18. UK: British Beet Research Organization. 
TAYLOR, J., WOOD, G., EARL, R. \& GODWIN, R. 2003. Soil factors and their influence on within-field crop variability.Part II: Spatial analysis and determination of management zones. Biosystems Engineering, 84,441-453.

WEBSTER, R. \& LARK, M. 2012. Field sampling for environmental science and management, Abingdon, Oxon-UK, Routledge.

WEBSTER, R. \& OLIVER, M. A. 2007. Geostatistics for environmental scientists,West Sussex-UK, Wiley.

WHALLEY, D. \& SIEGFRIED, H. C. 1964. ICUMSA methods of sugar analysis,New York-USA, Elsevier.

ZHANG, L., STEVEN, M., CLARKE, M. \& JAGGARD, K. 2007. Mapping soil water holding capacity at a within-field scale for precision irrigation. Proceedings 7th UK CARE Annual General Meeting, 15 September 2007, Greenwich-UK, UK Chinese Association of Resources and Environment pp. 1-9.

ZHANG, L., CLARKE, M., STEVENS, M. \& JAGGARD, K. 2011. Spatial patterns of wilting in sugar beet as an indicator for precision irrigation. Precision Agriculture, 12, 296-316.

ZHU, Q., LIN, H. \& DOOLITTLE, J. 2013. Functional soil mapping for site-specific soil moisture and crop yield management. Geoderma, 200, 45-54. 


\section{Supplementary information}

Suppl. Table 1: Geostatistical analysis for crop and environmental variables in the three fields, White Patch, T32 and WO3. Spatial dependency is the ratio of nugget: sill expressed as a percentage; the lower the value, the greater the spatial dependence. Soil nutrients all relate to available amounts.

\begin{tabular}{|c|c|c|c|c|c|c|c|c|c|c|c|c|c|c|c|}
\hline \multirow[b]{2}{*}{ Variables } & \multicolumn{5}{|c|}{ White Patch, 2012} & \multicolumn{5}{|c|}{ T32, 2012} & \multicolumn{5}{|c|}{ WO3, 2013} \\
\hline & Model & $\begin{array}{l}\text { Rang } \\
\text { (m) }\end{array}$ & $\begin{array}{l}\text { Sill } \\
\text { variance }\end{array}$ & $\begin{array}{l}\text { Nugget } \\
\text { variance }\end{array}$ & $\begin{array}{l}\text { Spatial } \\
\text { dependency }\end{array}$ & Model & $\begin{array}{l}\text { Range } \\
\text { (m) }\end{array}$ & $\begin{array}{l}\text { Sill } \\
\text { variance }\end{array}$ & $\begin{array}{l}\text { Nugget } \\
\text { variance }\end{array}$ & $\begin{array}{l}\text { Spatial } \\
\text { dependency }\end{array}$ & Model & $\begin{array}{l}\text { Range } \\
\text { (m) }\end{array}$ & $\begin{array}{l}\text { Sill } \\
\text { variance }\end{array}$ & $\begin{array}{l}\text { Nugget } \\
\text { variance }\end{array}$ & $\begin{array}{l}\text { Spatial } \\
\text { dependency }\end{array}$ \\
\hline Clay, \% & Spherical & 106 & 29.4 & 0 & 0 & Pentaspherical & 116 & 5.9 & 1.66 & 22 & Circular & 81 & 10.6 & 8.9 & 46 \\
\hline Sand, \% & Exponential & 190 & 49.8 & 6 & 11 & Pentaspherical & 305 & 6.8 & 6.2 & 48 & Circular & 85 & 15.4 & 10.7 & 41 \\
\hline Organic matter, \% & Exponential & 69 & 0.18 & 0.08 & 31 & Circular & 190 & 0.11 & 0.07 & 39 & Pentaspherical & 112 & 0.17 & 0.14 & 45 \\
\hline Soil pH & Exponential & 123 & 0.09 & 0 & 0 & Circular & 141 & 0.12 & 0.05 & 29 & Circular & 73 & 0.016 & 0.011 & 41 \\
\hline Electrical conductivity, $\mu S$ & Exponential & 106 & 282 & 88.4 & 23 & Circular & 127 & 340 & 283 & 45 & Circular & 58 & 157 & 270 & 63 \\
\hline Seasonal incident radiation, $\mathrm{J} / \mathrm{m}^{2}$ & Circular & 80 & 928 & 1110 & 54 & Pentaspherical & 261 & 535 & 579 & 52 & Exponential & 108 & 3875 & 721 & 16 \\
\hline Soil moisture, June, \% & Spherical & 64 & 33 & 8.6 & 20 & Exponential & 266 & 23.6 & 13.8 & 37 & Circular & 121 & 32 & 4.9 & 14 \\
\hline Soil moisture, July, \% & Spherical & 119 & 12.4 & 4.3 & 26 & Exponential & 270 & 27 & 4 & 13 & Circular & 114 & 27.5 & 5.3 & 16 \\
\hline Soil moisture, August, \% & Exponential & 127 & 24 & 1.76 & 7 & Spherical & 169 & 18 & 25 & 12 & Circular & 169 & 4.8 & 1.8 & 27 \\
\hline Roots yield, t/ha & Circular & 94 & 149 & 0 & 0 & Circular & 224 & 45.7 & 33 & 42 & Circular & 115 & 253.4 & 140.6 & 36 \\
\hline Yield value, $£ / h a$ & Circular & 93 & 144320 & 8152 & 5 & Circular & 241 & 48933 & 41956 & 46 & Circular & 117 & 190964 & 113393 & 37 \\
\hline Plant population /ha & Circular & 117 & 9.7 & 3.8 & 28 & Exponential & 315 & 9.2 & 0.9 & 49 & Exponential & 126 & 6.7 & 2.1 & 24 \\
\hline Amino acid, $\mathrm{mg} / 100 \mathrm{~g}$ beet & Exponential & 100 & 0.03 & 0.037 & 55 & Exponential & 380 & 1.2 & 0.99 & 45 & Exponential & 208 & 4.4 & 1.55 & 26 \\
\hline Potassium, mg/100g beet & Circular & 90 & 49 & 49.4 & 50 & Exponential & 255 & 74.8 & 24.4 & 25 & Pentaspherical & 122 & 93 & 77 & 45 \\
\hline Log soil phosphate, mg/L & Spherical & 207 & 0.35 & 0.26 & 43 & Pentaspherical & 93 & 0.82 & 0.51 & 38 & $\ldots$ & $\ldots$ & $\cdots$ & $\ldots$ & $\cdots$ \\
\hline Soil potassium, mg/L & Pure Nugget & $\ldots$ & $\ldots$ & $\ldots$ & $\ldots$ & $\cdots$ & $\ldots$ & $\ldots$ & $\ldots$ & $\ldots$ & Pure Nugget & $\ldots$ & $\ldots$ & $\ldots$ & $\ldots$ \\
\hline Log soil potassium, mg/L & $\ldots$ & $\cdots$ & $\ldots$ & $\cdots$ & $\cdots$ & Exponential & 180 & 0.013 & 0.012 & 48 & ... & $\cdots$ & $\cdots$ & $\cdots$ & $\cdots$ \\
\hline
\end{tabular}



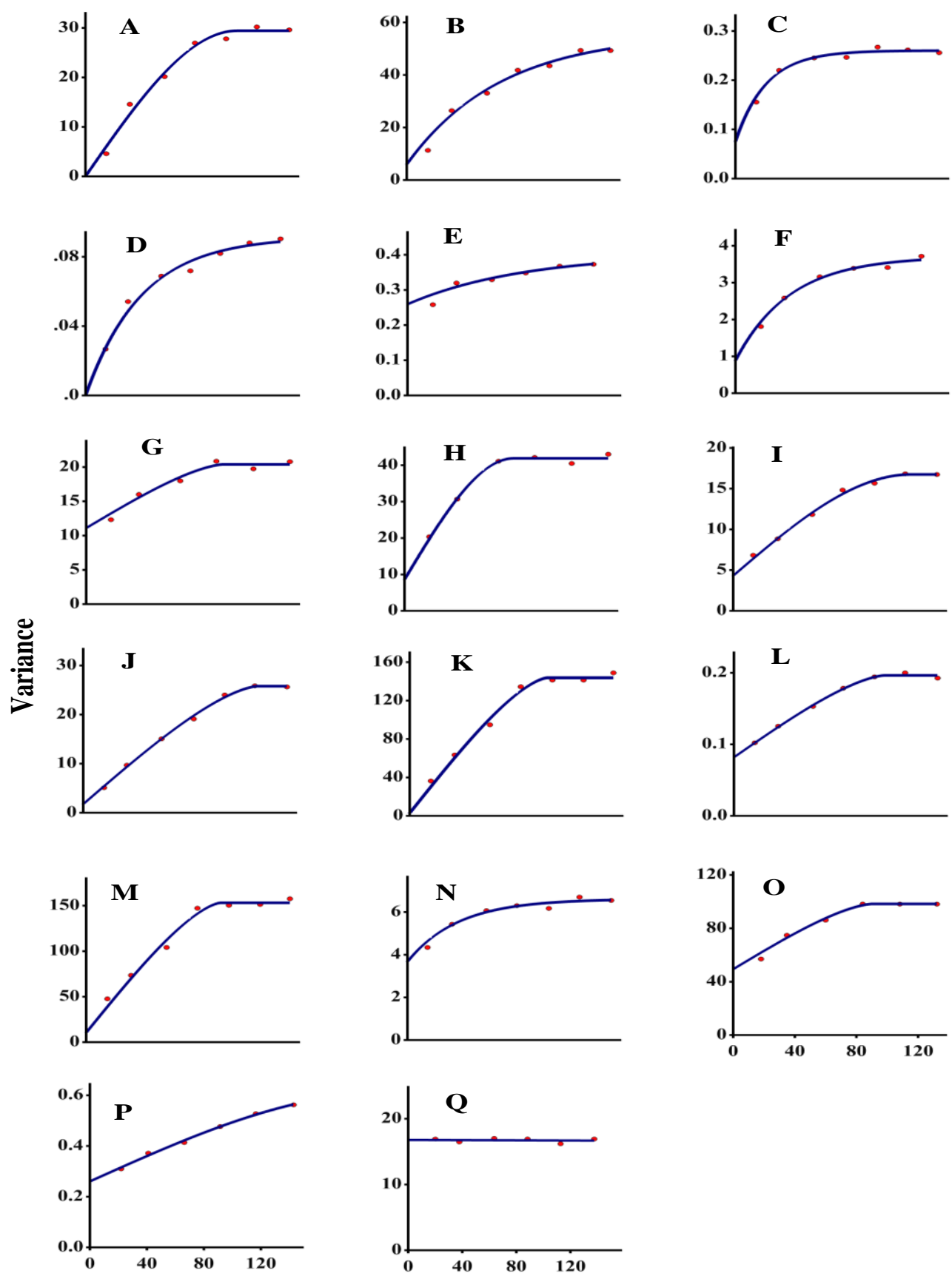

Lag distance, $m$

Suppl. Figure 1: The experimental variograms in White Patch field in 2012 for: (A) clay, \%; (B) sand, \%; (C) organic matter, \%; (D) soil pH; (E) log magnesium, mg/L; (F) electrical conductivity, $\mu \mathrm{S}$ (variance $\mathrm{x} 100$ ); $(\mathrm{G})$ seasonal incident radiation, $\mathrm{J} / \mathrm{m}^{2}$ (variance $\mathrm{x} 100$ ); soil volumetric moisture content, \%, in (H) June, (I) July and (J) August; (K) root yield, t/ha; (L) sugar, \%; (M) yield value, $£ /$ ha (variance x 1000); (N) log amino acid, mg/100g; (O) potassium in beets, mg/100g; (P) $\log$ available soil phosphate, mg/L; (Q) available soil potassium, mg/L. 

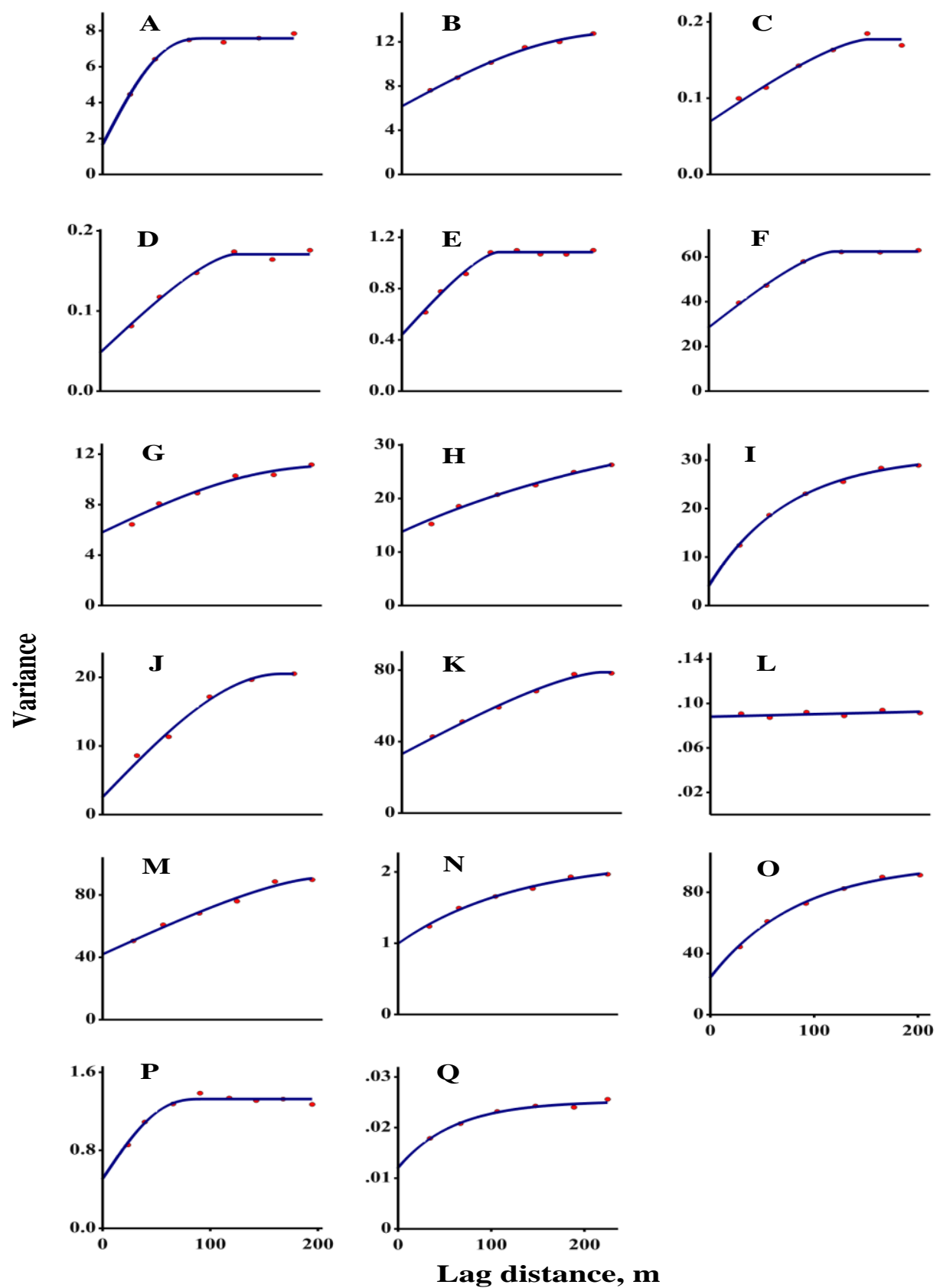

Suppl. Figure 2: The experimental variograms in T32 field in 2012 for: (A) clay, \%; (B) sand, \%; (C) organic matter, \%; (D) soil $\mathrm{pH}$; (E) log magnesium, mg/L; (F) electrical conductivity, $\mu \mathrm{S}$ (variance $\mathrm{x} 10$ ); (G) seasonal incident radiation, $\mathrm{J} / \mathrm{m}^{2}$ (variance $\mathrm{x} 100$ ); soil volumetric moisture content, \%, in (H) June, (I) July and (J) August; (K) root yield, t/ha; (L) sugar, \%; (M) yield value, $£ /$ ha (variance x 1000); (N) log amino acid, mg/100g; (O) potassium in beets, $\mathrm{mg} / 100 \mathrm{~g}$; (P) $\log$ available soil phosphate, mg/L; (Q) available soil potassium, mg/L. 

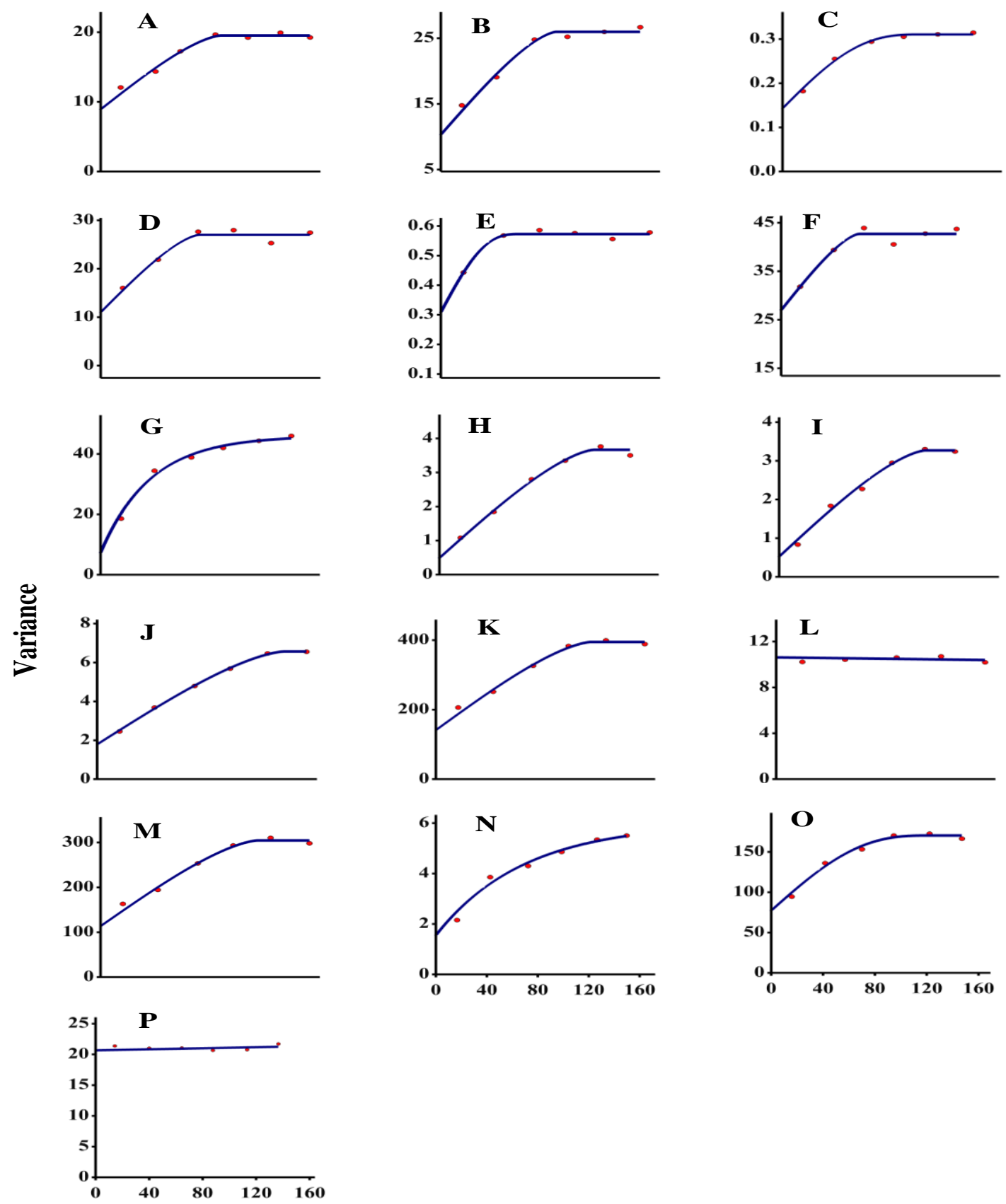

\section{Lag distance, $\mathbf{m}$}

Suppl. Figure 3: The experimental variograms in WO3 field in 2013 for: (A) clay, \%; (B) sand, \%;

(C) organic matter, \%; (D) soil $\mathrm{pH}$; (E) log magnesium, mg/L; (F) electrical conductivity, $\mu \mathrm{S}$ (variance $\mathrm{x} 10)$; (G) seasonal incident radiation, $\mathrm{J} / \mathrm{m}^{2}$ (variance $\left.\mathrm{x} 100\right)$; soil volumetric moisture content, \%, in (H) June, (I) July and (J) September; (K) root yield, t/ha; (L) sugar, \%; (M) yield value, $£ /$ ha (variance x 1000); (N) log amino acid, mg/100g; (O) potassium in beets, mg/100g; (Q) available soil potassium, $\mathrm{mg} / \mathrm{L}$. 


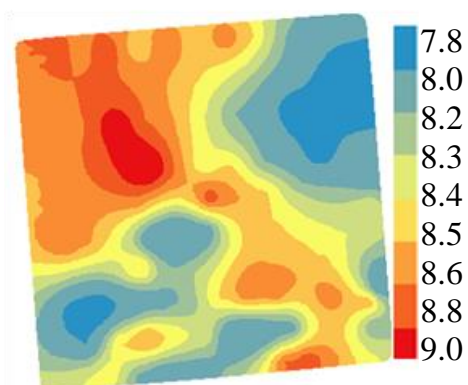

A. Soil $\mathrm{pH}$

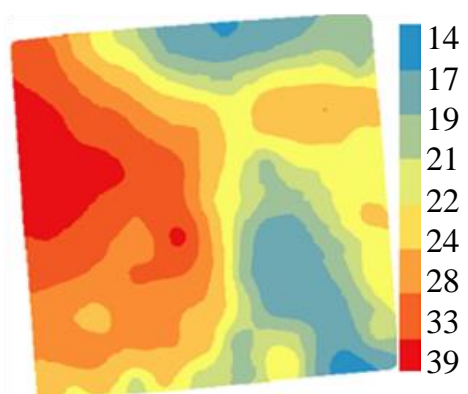

D. Soil moisture in August, \%

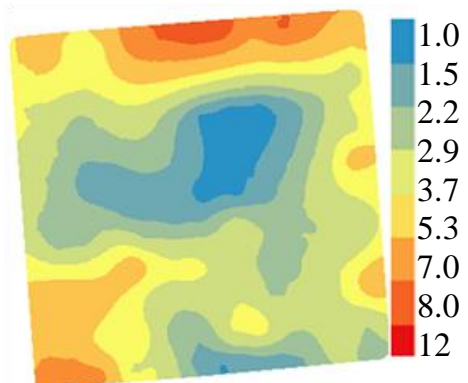

G. Soil available $\mathrm{P}, \mathrm{mg} / \mathrm{L}$

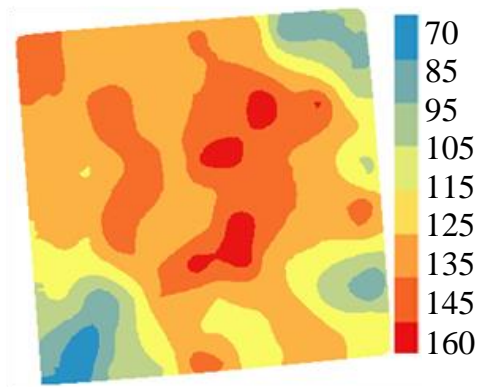

B. Soil EC, $\mu \mathrm{S}$

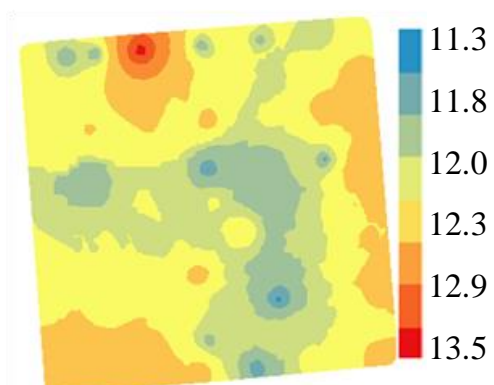

E. Min canopy temperature, ${ }^{\circ} \mathrm{C}$

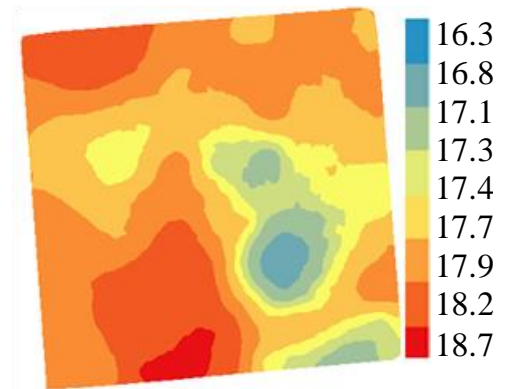

H. Sugar, \%

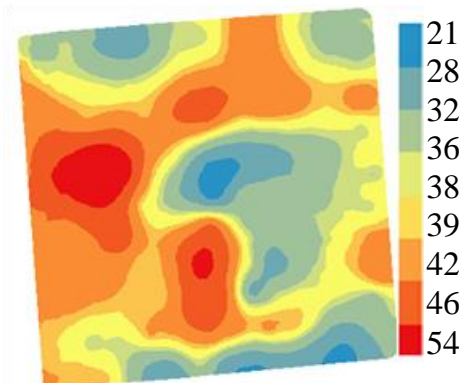

C. Soil moisture in June, \%

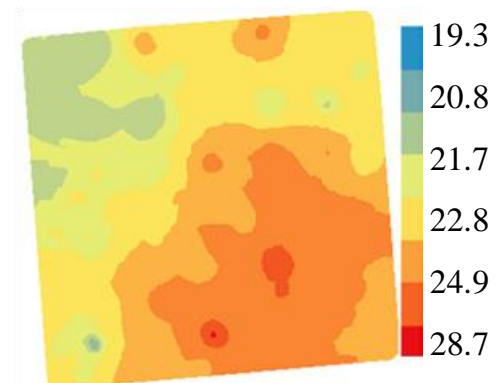

F. Max canopy temperature, ${ }^{\circ} \mathrm{C}$

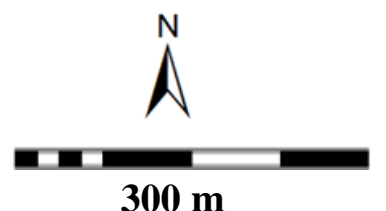

$300 \mathrm{~m}$

Suppl. Figure 4: Interpolation maps of some environmental variables and beet sugar concentration in White Patch in 2012. 


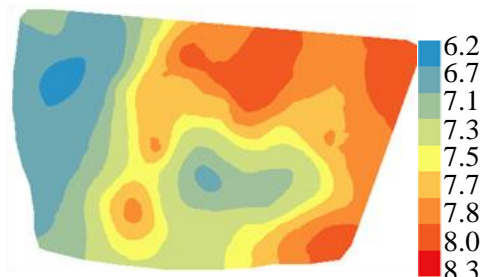

A. Soil $\mathrm{pH}$

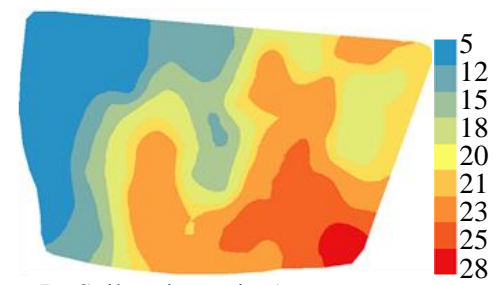

D. Soil moisture in August, \%

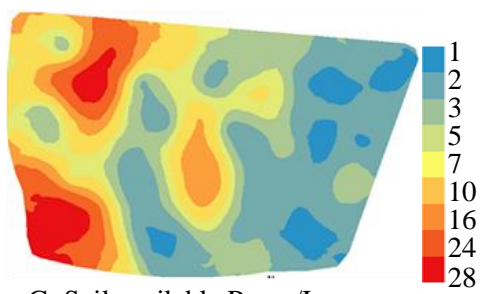

G. Soil available $\mathrm{P}, \mathrm{mg} / \mathrm{L}$

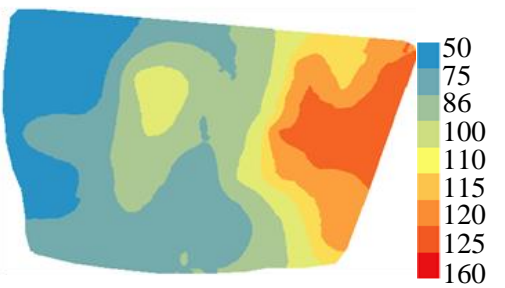

B. Soil EC, $\mu \mathrm{S}$

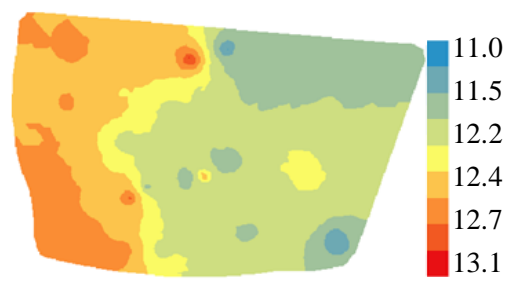

E. Min canopy temperature, ${ }^{\circ} \mathrm{C}$

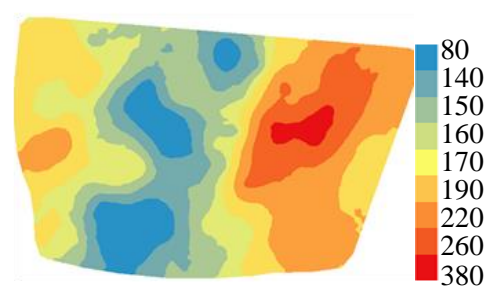

H. Soil available K, mg/L

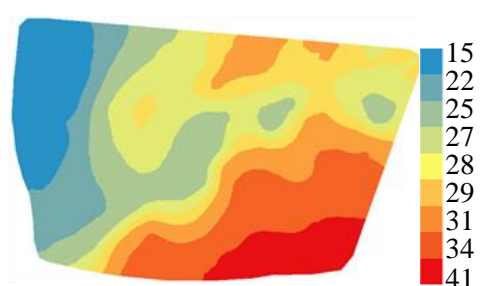

C. Soil moisture in June, \%
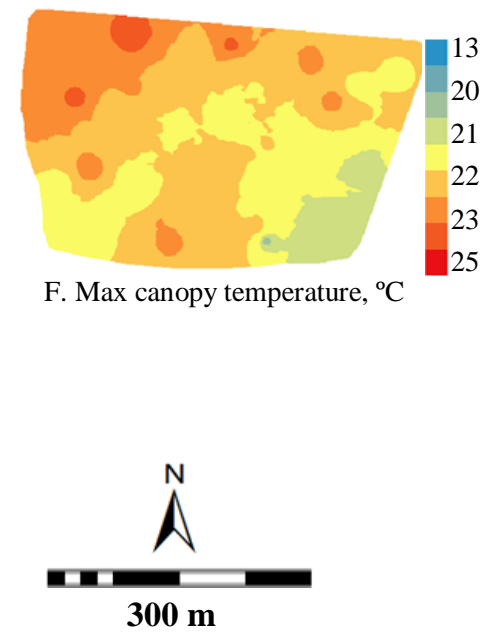

Suppl. Figure 5: Interpolation maps of some environmental variables in T32 in 2012. 


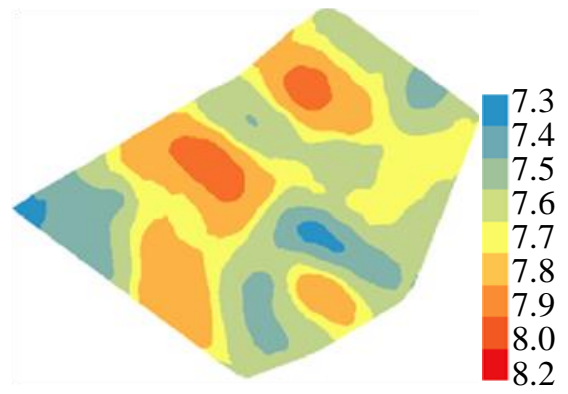

A. Soil pH

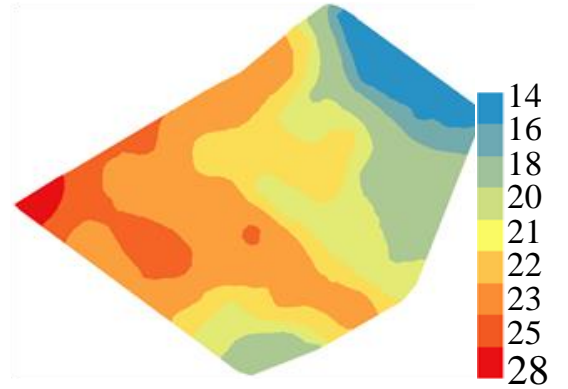

D. Soil moisture in September, \%

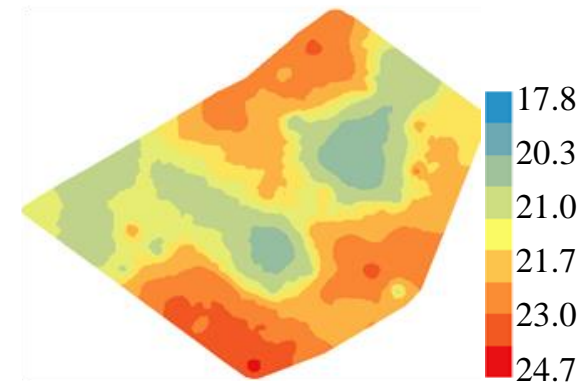

G. Max canopy temperature, ${ }^{\circ} \mathrm{C}$

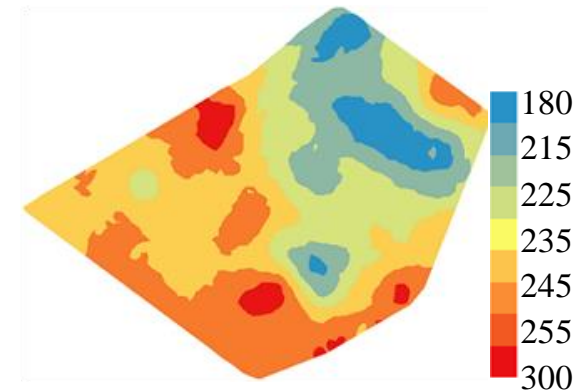

B. Soil EC, $\mu \mathrm{S}$

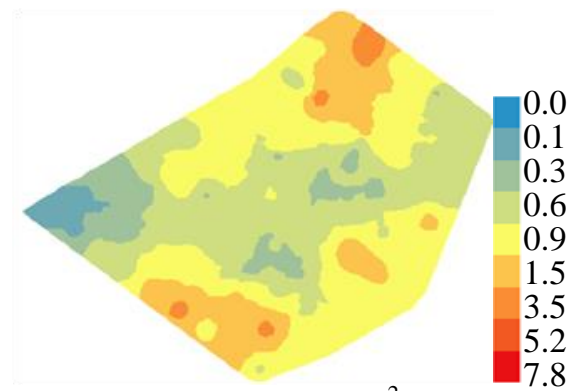

E. Weed density, $\mathrm{m}^{2}$

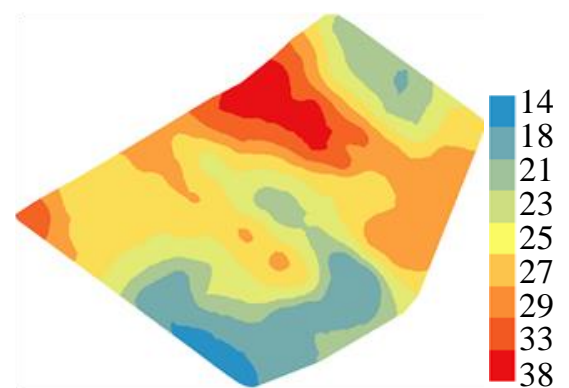

C. Soil moisture in June, \%

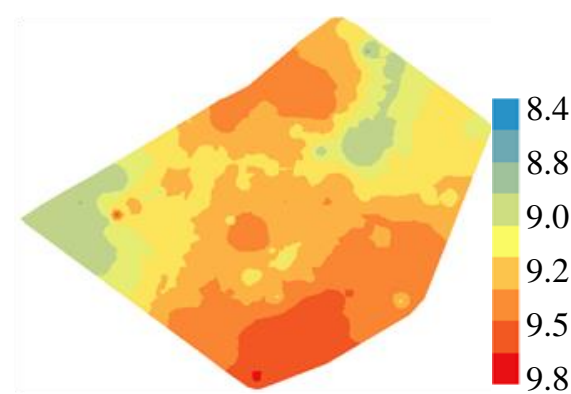

F. Min canopy temperature, ${ }^{\circ} \mathrm{C}$

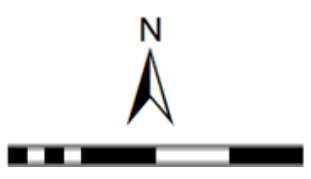

$300 \mathrm{~m}$

Suppl. Figure 6: Interpolation maps of some environmental variables and of weed density in WO3 in 2013. 
Suppl. Table 2: Correlations of sugar beet yield and quality and environmental variables in the fields, White Patch, T32 and W03.Numbers are overall Pearson correlation coefficients for the fields; values in bold differ significantly from zero $(P<0.05)$.

\begin{tabular}{|c|c|c|c|c|c|c|c|c|c|c|c|c|c|c|c|}
\hline & \multicolumn{5}{|c|}{ White Patch } & \multicolumn{5}{|c|}{$\underline{\text { T32 }}$} & \multicolumn{5}{|c|}{ WO3 } \\
\hline & \multirow[b]{2}{*}{$\begin{array}{r}\text { Plant } \\
\text { popul- } \\
\text { ation }\end{array}$} & \multirow[b]{2}{*}{$\begin{array}{l}\text { Root } \\
\text { yield }\end{array}$} & \multicolumn{3}{|c|}{ Beet content of } & \multirow[b]{2}{*}{$\begin{array}{l}\text { Plant } \\
\text { popul- } \\
\text { ation }\end{array}$} & \multicolumn{4}{|c|}{ Beet content of } & \multirow[b]{2}{*}{$\begin{array}{r}\text { Plant } \\
\text { popul- } \\
\text { ation }\end{array}$} & \multirow[b]{2}{*}{$\begin{array}{l}\text { Root } \\
\text { yield }\end{array}$} & \multicolumn{3}{|c|}{ Beet content of } \\
\hline & & & Sugar & $\begin{array}{r}\text { Amino } \\
\text { acid }\end{array}$ & $\begin{array}{l}\text { Pot- } \\
\text { assium }\end{array}$ & & $\begin{array}{l}\text { Root } \\
\text { yield }\end{array}$ & Sugar & $\begin{array}{r}\text { Amino } \\
\text { acid }\end{array}$ & $\begin{array}{r}\text { Pot- } \\
\text { assium }\end{array}$ & & & Sugar & $\begin{array}{r}\text { Amino } \\
\text { acid }\end{array}$ & $\begin{array}{r}\text { Pot- } \\
\text { assium }\end{array}$ \\
\hline \multicolumn{16}{|l|}{ Soil properties } \\
\hline Clay, \% & -0.07 & 0.36 & -0.01 & -0.06 & 0.19 & 0.08 & 0.09 & 0.1 & 0.19 & 0.21 & -0.34 & -0.33 & -0.26 & 0.11 & 0.45 \\
\hline Sand, $\%$ & 0.10 & -0.27 & 0.01 & 0.05 & -021 & -0.18 & -0.27 & -0.15 & -0.22 & -0.02 & 0.38 & 0.41 & $\mathbf{0 . 3 3}$ & -0.18 & -0.44 \\
\hline Organic matter, $\%$ & 0.18 & 0.51 & 0.12 & 0.0 & 0.08 & 0.32 & $\mathbf{0 . 3 5}$ & 0.01 & 0.09 & -0.54 & 0.17 & 0.33 & 0.15 & -0.06 & -0.06 \\
\hline $\mathrm{pH}$ & -0.02 & -0.01 & -0.21 & -0.19 & -0.09 & 0.15 & 0.25 & 0.05 & 0.24 & -0.15 & -0.10 & -0.05 & -0.07 & -0.20 & -0.16 \\
\hline $\mathrm{EC}, \boldsymbol{\mu} \mathrm{S}$ & 0.08 & 0.056 & -0.09 & -0.13 & -0.08 & 0.13 & 0.15 & 0.05 & 0.16 & -0.04 & 0.07 & -0.015 & -0.20 & 0.22 & 0.13 \\
\hline Available phosphate, $\mathrm{mg} / \mathrm{L}$ & 0.15 & -0.03 & 0.14 & 0.12 & 0.09 & -0.18 & -0.17 & 0.08 & -0.29 & 0.03 & 0.10 & -0.01 & -0.17 & -0.09 & -0.09 \\
\hline Available potassium, mg/L & -0.19 & -0.13 & 0.15 & 0.05 & 0.13 & -0.05 & -0.14 & 0.14 & 0.19 & 0.09 & 0.10 & 0.05 & 013 & -0.09 & -0.02 \\
\hline Available magnesium, mg/L & -0.06 & 0.04 & 0.03 & -0.10 & 0.10 & 0.15 & -0.19 & -0.16 & -0.03 & 0.06 & 0.29 & 0.33 & 0.16 & -0.03 & -0.09 \\
\hline \multicolumn{16}{|l|}{ Soil moisture content, \% } \\
\hline June & 0.04 & 0.47 & 0.15 & -0.11 & 0.16 & 0.24 & 0.33 & 0.06 & 0.27 & -0.02 & 0.40 & 0.56 & 0.30 & -0.37 & -0.44 \\
\hline July & 0.10 & 0.45 & 0.07 & -0.09 & 0.25 & 0.28 & 0.52 & -0.01 & 0.18 & -0.24 & 0.23 & 0.37 & 0.18 & -0.07 & -0.30 \\
\hline August or September & 0.13 & 0.53 & 0.25 & -0.06 & 0.36 & 0.23 & 0.47 & 0.08 & 0.34 & -0.12 & 0.20 & 0.23 & -0.16 & 0.13 & -0.08 \\
\hline \multicolumn{16}{|l|}{ Canopy temperature ${ }^{\circ} \mathrm{C}$} \\
\hline Mean & -0.25 & -0.32 & -0.11 & -0.15 & -0.16 & -0.07 & -0.16 & 0.1 & -0.24 & -0.05 & -0.30 & -0.27 & -0.09 & 0.05 & 0.22 \\
\hline Minimum & -0.09 & 0.09 & 0.28 & -0.03 & 0.13 & -0.39 & -0.22 & 0.16 & -0.37 & 0.013 & -0.29 & -0.24 & -0.15 & 0.10 & 0.28 \\
\hline Maximum & 0.23 & -0.56 & -0.23 & -0.14 & -0.01 & -0.04 & -0.25 & -0.03 & -0.18 & 0.07 & -0.30 & -0.33 & -0.21 & 0.11 & 0.34 \\
\hline Incident radiation, $\mathbf{J} / \mathbf{m}^{2}$ & -0.28 & -0.30 & -0.04 & 0.05 & 0.14 & -0.14 & -0.10 & -0.10 & -0.17 & 0.06 & -0.26 & -0.18 & -0.03 & -0.09 & -0.11 \\
\hline Elevation, $\mathrm{m}$ & -0.47 & 0.27 & -0.05 & 0.35 & 0.32 & 0.04 & -0.10 & 0.12 & 0.23 & 0.14 & -0.46 & -0.51 & -0.34 & 0.51 & 0.20 \\
\hline Weed density/m² & -0.06 & -0.40 & -0.06 & -0.28 & -0.31 & -0.24 & -0.50 & 0.11 & -0.39 & 0.03 & -0.11 & -0.22 & -0.12 & -0.01 & 0.16 \\
\hline Plant population /ha & & 0.51 & & & & & 0.51 & & & & & 0.72 & & & \\
\hline \multicolumn{16}{|l|}{ Beet quality } \\
\hline Sugar, $\%$ & -0.06 & 0.02 & - & & & -0.06 & -0.11 & - & & & 0.23 & 0.34 & - & & \\
\hline Amino acid, $\mathrm{mg} / 100 \mathrm{~g}$ beet & -0.25 & -0.02 & 0.06 & & & 0.38 & 0.36 & -0.32 & & & -0.18 & -0.17 & -0.34 & & \\
\hline Potassium, $\mathrm{mg} / 100 \mathrm{~g}$ beet & -0.36 & 0.03 & 0.31 & & & -0.31 & -0.18 & -0.16 & & & -0.45 & -0.52 & -0.31 & & \\
\hline
\end{tabular}


